University of Michigan Law School

University of Michigan Law School Scholarship Repository

Law \& Economics Working Papers

$4-1-2010$

\title{
The Relation between Firm-Level Corporate Governance and \\ Market Value: a Study of India
}

\author{
Bala Balasubramanian \\ Indian Institute of Management Bangalore, laba@iimb.ernet.in \\ Bernard S. Black \\ University of Texas School of Law, bblack@northwestern.edu \\ Vikramaditya Khanna \\ University of Michigan Law School, vskhanna@umich.edu
}

Follow this and additional works at: https://repository.law.umich.edu/law_econ_current

Part of the Business Organizations Law Commons, and the Law and Economics Commons

\section{Working Paper Citation}

Balasubramanian, Bala; Black, Bernard S.; and Khanna, Vikramaditya, "The Relation between Firm-Level Corporate Governance and Market Value: a Study of India" (2010). Law \& Economics Working Papers. 10. https://repository.law.umich.edu/law_econ_current/art10

This Article is brought to you for free and open access by University of Michigan Law School Scholarship Repository. It has been accepted for inclusion in Law \& Economics Working Papers by an authorized administrator of University of Michigan Law School Scholarship Repository. For more information, please contact mlaw.repository@umich.edu. 


\title{
The Relation Between Firm-level Corporate Governance and Market Value: A Case Study of India
}

\author{
By: N. Balasubramanian* Bernard S. Black ${ }^{\dagger}$ \& Vikramaditya Khannatt
}

\section{Introduction}

We know relatively little about the corporate governance practices of public firms in emerging markets. This paper offers two principal contributions. First, we provide a detailed, "case study" of firm-level governance practices in an emerging market, based on a 2006 survey of Indian firms. India is a logical choice for this effort - it is the second largest emerging market based on both population and GDP (after China), and the largest emerging market with a significant number of non-government-controlled public firms. We are not aware of comparable efforts in other countries, other than a contemporaneous effort by one of us in Brazil, with a smaller sample (Black, de Carvalho and Gorga, 2008).

Second, we contribute to the literature on corporate governance indices and the connection between governance and firm market value. We build a broad overall Indian Corporate Governance Index (ICGI) and find a positive association between ICGI and firm market value. These results are broadly consistent with those from multi-country studies (e.g., Klapper and Love, 2004; Durnev and Kim, 2005). However, the multi-country studies cover only the largest firms in each country. We find that the association between ICGI and firm market value extends to, and may be stronger for, smaller firms.

We also investigate the role of particular aspects of governance, such as board structure, in predicting firms' market values. Some other studies (Dahya, Dimitriev and McConnell, 2008 (crosscountry), Black and Kim, 2008 (Korea)) find a positive association between board structure and firm market value. We do not; see also Black, de Carvalho and Gledson (2008) (negative association in Brazil). Our results thus cast doubt on how much we yet know about what matters in governance. The association between an overall index and firm market value, found in a number of individual countries as well as in cross-country studies ([cites to come]), breaks down when one investigates which aspects of governance underlie the overall relationship.

\footnotetext{
* Professor Finance, Indian Institute of Management, Bangalore. Email: laba@,iimb.ernet.in.

$\dagger$ Hayden W. Head Regents Chair for Faculty Excellence and Professor of Law, University of Texas Law School \& Professor of Finance, Red McCombs School of Business. Email: bblack@law.utexas.edu.

+t Louis \& Myrtle Moskowitz Research Professor of Business and Law and Professor of Law, University of Michigan Law School. Harvard Law School S.J.D. 1997. Email: vskhanna@,umich.edu. We thank the International Corporate Governance Forum-Asian Centre for Corporate Governance International Conference on Corporate Governance: Role of Corporate Governance in Improving India's Investment Climate, India Business Investor Dialogue sponsored by the Global Corporate Governance Forum and the Securities \& Exchange Bureau of India, and the IndiaChina Corporate Governance Conference, Virginia Beach for helpful comments and suggestions and Sheena Paul, Andrew Schwaitzberg, and Mandy Tham for excellent research assistance. We thank Pedro Matos and Miguel Ferreira for sharing their data on which Indian firms are included in the Morgan Stanley Capital International Index. We also thank the Dean's Fund, University of Michigan Law School, John M. Olin Center at the University of Michigan Law School, Center for International Business Education \& Research, Stephen Ross School of Business, University of Michigan, Center for International Business Education \& Research, Red McCombs School of Business, University of Texas, and the Global Corporate Governance Forum of the International Finance Corporation for funding support. We also thank the Indian Institute of Management, Bangalore and the Bombay Stock Exchange for their support throughout the process.
} 
Our findings, especially when combined with those from other countries, suggest that the benefits of particular corporate governance practices vary depending on firm and country characteristics. This suggests that governance is not one-size fits all (see also Arcot and Bruno, 2006; Bruno and Claessens, 2007; Black, de Carvalho and Gorga, 2010). A combination of some mandatory minimum rules (perhaps differing based on firm size) and flexibility above the minimum level - for example, by allowing firms to self select levels of governance (as in Brazil) or comply-orexplain regimes (as in the UK and Continental Europe) -- may prove more valuable than legal regimes that rely primarily on mandatory rules.

Part II summarizes the relevant literature and India's corporate governance history. Part III discusses our survey methodology and data sources. Part IV discusses survey results. Part V defines a corporate governance index and examines the relationship between index scores and firm market value. Part VI discusses some implications of our study for what matters in corporate governance in emerging markets. Part VII concludes.

\section{Literature Review}

We review here the literature on two aspects of governance in emerging markets: what we know about governance patterns, and to what extent does governance predict firm share prices or performance. We cover studies of India with care, and other studies in less depth. We do not cover developed countries or nonpublic firms.

\section{A. What We Know About Firm-Level Governance in Emerging Markets}

This paper's first goal is to provide a detailed descriptive analysis of firm-level governance in an important emerging market. We know remarkably little about the details of firm-level governance. Cross-country studies of governance provide high level comparisons between countries -- for example, mean scores on disclosure (Patel, Balic and Bwakira, 2002) or overall governance (Bruno and Claessens, 2010) -- but few details. Individual country studies report summary statistics for overall governance and particular governance measures, but again few details. To our knowledge, the most directly comparable paper is contemporaneous research on Brazil (Black, de Carvalho, and Gorga, 2010a; 2010b).

Several studies examine Indian corporate governance generally. Khanna (2009) reviews the development of corporate governance norms in India from independence to the present. World Bank (2005), Sarkar \& Sarkar (2000), and Mohanty (2003) examine how firm-level governance influences the behavior of institutional investors, or vice-versa. Mohanty (2003) finds that institutional investors own a higher percentage of the shares of better-governed Indian firms. This is consistent with research in other countries (Aggarwal, Klapper and Wysocki, 2005; Ferreira and Matos, 2007).

Zattoni, Pedersen and Kumar (2009) and Singh and Gaur (2009) examine the association between business group membership and performance with conflicting results. Jackling \& Johl study the association between board structure and firm performance in large Indian firms and find an association between board size and Tobin's q, but report only three stage least squares results, with unconvincing instruments. Bhattacharyya and Rao (2005) examine whether adoption of Clause 49 (an important set of governance reforms in India) predicts lower volatility and returns for large Indian firms. Black \& Khanna (2007) conduct an event study of the adoption of Clause 49 and report positive returns to a treatment group of large firms (who were required to comply quickly) relative to small firms (for whom compliance was delayed), around the first important legislative 
announcement. Dharmapala and Khanna (2009) report that small Indian firms which are subject to Clause 49 react positively to plans by the Securities and Exchange Board of India (SEBI) -- India's securities regulator -- to enforce the Clause, relative to similar firms not subject to Clause 49.

Other studies of Indian firms are more peripherally related. Khanna, Kogan and Palepu (2006), study instances of minority shareholder expropriation by Indian firms. Bertrand, Mehta and Mullainathan (2002) provide evidence on tunneling within Indian business groups. Deb and Chaturvedula (2004) study the relationship between ownership concentration and firm market value.

\section{B. Does Governance Predict Firm Value in Emerging Markets?}

A second goal of this paper is to contribute to the literature on the connection between firm-level governance and firm market values in emerging markets. A number of cross-country studies examine this connection (e.g., Aggarwal, Erel, Stulz and Williamson, 2006; Klapper and Love, 2004; Durnev and Kim, 2005; Doidge, Karolyi and Stulz, 2007;; see also the survey by Love (2010). However, these studies have important weaknesses, including: they rely on one of two available indices, each imperfect; ${ }^{1}$ they cover only the largest firms in each country; and they have limited control variables (which increases the risk of omitted variable bias).

Individual country studies, such as this one, have different strengths and weaknesses, and can complement the cross-country studies. These studies are of uncertain generalizability. However, they allow one to: (i) study the association between governance and performance at both large and small firms; (ii) develop, as we do here, a country-specific governance index which reflects a particular country's rules and norms; (iii) use current indices . In contrast, the S\&P and CLSA indices are already becoming dated, and have other important limitations (the S\&P index is limited to disclosure; CLSA relies in part on analysts' subjective opinions). The principal studies which develop and assess overall governance measures for emerging markets include:

- Brazil (Leal and Carvalhal-da-Silva, 2007; Black, de Carvalho and Gorga, 2010b)

- Hong Kong (Cheung, Connelly, Limpaphayom and Zhou, 2007)

- Korea (Black, Jang and Kim, 2006a)

- Russia (Black, 2001; Black, Love and Rachinsky, 2006).

\section{Survey Methodology and Data Sources}

\section{A. Survey Methodology}

This study relies on an extensive survey we conducted in early 2006 of 506 Indian public companies ("India CG Survey 2006"). We received 370 responses (73\% response rate). ${ }^{2}$ We surveyed firms with central offices in one of India's six largest cities -- Bangalore, Chennai, Hyderabad, Kolkata, Mumbai, and New Delhi. We approached all firms in the BSE 200 index with

1 These are: Standard \& Poor's transparency and disclosure index (2002; only disclosure); and Credit Lyonnais Securities Asia survey (2001; some questions are subjective; responses could be influenced by firm performance).

2 A copy of the survey is available on request from the authors. Most respondents held senior positions at their firms (309 were chief legal officer or company secretary; 42 were CFO or other senior finance official; 10 were the CEO). The survey was supported by the Bombay Stock Exchange (BSE) and IIM Bangalore, one of India's top business schools. We mailed a survey to each firm, did followup mailings and phone calls, and engaged the A.C. Nielsen survey research firm to visit firms. The higher response rates for BSE 201-500 firms and non-BSE-500 firms (see Table 1) could reflect a tendency for A.C. Nielsen to contact firms with whom they had prior relationships. We promised confidentiality to respondents, and thus do not name individual firms in this paper. 
central offices in these cities; these firms include 26 of the firms in the BSE 30 index and 131 of the BSE 200 firms. $^{3}$ For smaller firms, we asked A.C. Nielsen to select firms at random, with a tilt toward firms in the BSE 500 index. Overall, we approached 275 firms in the BSE 500 (55\%); these firms represent $80 \%(76 \%)$ of the market capitalization of the BSE 500 (all Indian public firms). For details on the survey questions, see Balasubramanian, Black and Khanna (2009).

The size and other financial characteristics of approached firms are similar to nonapproached firms and those of responding firms are similar to nonresponding firms. Thus, sample selection bias is likely to be limited, relative to all Indian private firms large enough to be included in the Prowess financial database (the principal source of financial information for Indian firms, similar to a combined Compustat and CRSP for U.S. firms). We did not study very small firms which are publicly listed, but rarely trade and are not covered by Prowess. ${ }^{4}$

Table 1 provides summary information on the firms we approached and those which responded. The response rates exceeded $50 \%$ for all BSE group ranges.

\section{Table 1. Surveyed and Responding Firms}

Number of firms approached and number of respondents in different size ranges, for India CG Survey 2006. Total row includes all firms in Prowess database (database of Indian public firms.

\begin{tabular}{|l|c|c|c|}
\hline Size Group & $\begin{array}{c}\text { No in } \\
\text { group }\end{array}$ & $\begin{array}{c}\text { Approached(\% of } \\
\text { total) }\end{array}$ & $\begin{array}{c}\text { Responses (\% of } \\
\text { surveyed) }\end{array}$ \\
\hline BSE 30 & 30 & $26(87 \%)$ & $20(77 \%)$ \\
\hline BSE 31-100 & 70 & $45(64 \%)$ & $26(58 \%)$ \\
\hline BSE 101-200 & 100 & $61(61 \%)$ & $31(51 \%)$ \\
\hline BSE 201-500 & 300 & $143(47 \%)$ & $82(56 \%)$ \\
\hline Subtotal BSE 500 & $\mathbf{5 0 0}$ & $\mathbf{2 7 5 ( 5 5 \% )}$ & $\mathbf{1 6 0 ( 5 8 \% )}$ \\
\hline Other & 2,007 & $231(15 \%)$ & $210(91 \%)$ \\
\hline Total & $\mathbf{2 , 5 0 7}$ & $\mathbf{5 0 6 ( 2 0 \% )}$ & $\mathbf{3 7 0 ~ ( 7 3 \% )}$ \\
\hline
\end{tabular}

Of the 370 respondents, 31 were government-controlled, 38 were foreign-controlled. ${ }^{5}$ Our analysis below focuses on the remaining 301 firms, which we term "Indian private firms." The response rate for these firms was 77\% (301/393). Of these 301 firms, 55\% are part of an Indian business group which includes one or more other public firms; $69 \%$ have a $40 \%$ or greater shareholder.

3 The standard stock price indices for Indian firms are BSE 30 (also called Sensex); BSE 100, BSE 200, BSE 500 and, for the National Stock Exchange, the Nifty Fifty. Most large Indian firms are listed on both exchanges.

4 Respondents might self-report with bias, but it seems likely that this bias is not severe. First, a significant number of firms do not comply with Indian rules on board independence, which is verifiable from both their annual reports and their survey responses. This suggests that firms do not expect significant consequences from noncompliance. Given this, plus our promise of confidentiality, firms had little reason to misreport to us. Second, for some governance elements, we have data both from annual reports (which are public, hence misreporting may be riskier) and from our survey; there are occasional differences between the two sources, but no systematic differences.

5 We classified as foreign-controlled firms with a majority foreign owner or a $40 \%$ foreign owner who held more than any other shareholder. We classified as government-controlled 25 firms which are majority owned by the central government or a state government, 5 firms with at least 39\% government ownership, and Cement Corp. of India, which has missing ownership data. Prowess classifies all of these firms as government firms. No firms have between $11 \%$ and $39 \%$ government ownership. 


\section{Indian Corporate Governance Overview}

This Part provides a detailed overview of the corporate governance of Indian private firms. Results are based only on responding firms except as noted. Balasubramaniam, Black and Khanna (2009) provide additional details and citations to the applicable legal rules.

\section{A. Board Composition and Independence}

The principal sources of Indian corporate governance rules are the Company Law and "Clause 49" of the stock exchange listing requirements, issued by the Indian securities regulator, SEBI (Securities and Exchange Board of India). Clause 49 requires listed firms with net worth greater than Rs. 25 crores ( 1 crore $=10^{7}$ rupees $\approx$ US $\$ 200,000$ ) or paid up share capital greater than Rs. 3 crores at any time in their history to have either a majority of independent directors, or at least $1 / 3$ independent directors plus a board chairman who is not the CEO (but need not be independent, and often represents the controlling family or business group). Table 2 provides information on board composition. Larger firms have larger boards (Pearson correlation between $\ln$ (market capitalization), and board size $=0.20, \mathrm{p}<.01)$.

Some Indian firms have complained that it can be hard for them to find qualified independent directors. Table 2 suggests that most surveyed firms can find independent directors; how qualified, we do not know.

\section{Table 2. Percentages of Different Types of Directors}

Sample is 295 firms with board composition data which responded to India CG Survey 2006.

\begin{tabular}{|c|c|c|c|c|}
\hline Percentage range & Inside & $\begin{array}{c}\text { Nonexecutive } \\
\text { (not indep.) }\end{array}$ & Independent & $\begin{array}{c}\text { Separate CEO and chairman } \\
\text { (for firms in range for } \\
\text { independent directors) }\end{array}$ \\
\hline $\mathbf{0 \%}$ & 7 & 152 & 7 & 2 \\
\hline $\mathbf{1 - 3 2} \%$ & 121 & 97 & 13 & 9 \\
\hline $\mathbf{3 3 - 4 9 \%}$ & 98 & 31 & 68 & 50 \\
\hline $\mathbf{5 0 \%}$ & 35 & 4 & 70 & 67 \\
\hline $\mathbf{5 1 - 7 4 \%}$ & 31 & 9 & 108 & 13 \\
\hline $\mathbf{7 5 - 1 0 0 \%}$ & 3 & 2 & 29 & $\mathbf{1 7 5}(\mathbf{5 9} \% \mathbf{)}$ \\
\hline Total & $\mathbf{2 9 5}$ & $\mathbf{2 9 5}$ & $\mathbf{2 9 5}$ & \\
\hline mean (median) $\%$ & $35 \%(33 \%)$ & $12.7 \%(0 \%)$ & $53 \%(50 \%)$ & \\
\hline $\begin{array}{c}\text { mean (median) } \\
\text { number of directors }\end{array}$ & $2.82(3)$ & $1.09(0)$ & $4.35(4)$ & \\
\hline
\end{tabular}

The final column of Table 2 shows the number of firms, within a particular range for percentage of independent directors, who have separate CEO and chairman. This practice is common; it is followed by 175 (59\%) of responding firms. However, 20 firms (7\%) do not comply with the requirement of at least 33\% independent directors. In addition, of the 68 firms with 33$49 \%$ independent directors, 18 do not have a separate CEO and chairman; and thus also do not comply with Clause 49. In all, 257 firms (87\%) comply with the board independence rules.

If the independence rules are appropriate (a topic we do not explore here), this level of noncompliance could be worrisome. Yet, in assessing the reliability of survey responses, reports of non-compliance may be good news. That some firms reported not complying with Clause 49 gives us more confidence that firms who report complying in fact comply. 
We also asked about director backgrounds. Clause 49 requires firms to have an audit committee, and requires the audit committee to have at least one person with financial or accounting expertise; $96 \%$ of firms comply. Over $20 \%$ of firms have a director who explicitly represents minority shareholders or institutional investors. There is a fair bit of gender diversity, with $30 \%$ of firms having a female director (but typically only one).

Some aspects of firms' choices for directors provide some basis for concern. One may doubt the business expertise of a typical scholar. Yet 39\% of firms turn to scholars to fill the ranks of independent directors, and often add several such persons to their boards; the mean number of scholar-directors for firms which take this route is 2.6. A similar percentage of firms have a lawyer on the board, but typically only one. Perhaps reflecting the importance of government regulation and political connections, $30 \%$ of firms have a former government official or former politician on their board. ${ }^{6}$

\section{B. Board Practices and Processes}

We turn next to the survey questions that assess board practices and processes. These are summarized in Table 3, along with an indication of which practices are legally required practices, and when the requirement was adopted.

Indian law allows director terms to be up to 5 years but also requires either (i) annual terms or (ii) at least two-thirds of the directors should serve staggered terms, with a 3-year maximum. Most firms use multiyear terms for both executive and nonexecutive directors, usually 3 or 5 years for executives and 3 years for nonexecutives.

Indian law requires at least 4 board meetings per year, with no more than 3 months between meetings. All but eight firms met this rule; the median number of physical meetings per year is 6 . However, three outlier firms reported that their board never met during the year! Only 11\% of firms reported sometimes using phone or other electronic meetings, instead of physical meetings. Indian law requires firms to prepare minutes for board and board committee meetings. Almost all firms prepare minutes for meetings of board committees. Only $75 \%$ said that dissents would be recorded in the minutes. However, some "no" answers could reflect lack of dissents, rather than a practice of not recording them.

${ }^{6}$ By comparison, Choi, Park and Yoo (2007) report, for Korean directors over 1999-2002 (period of rapid change in Korean boards, partly due to legal mandates), the average firm had 32\% outside directors; $25 \%$ of firms had one or more academics as directors; $16 \%$ had one or more lawyers, and 13\% had one or more former politicians or government officials. 


\section{Table 3. Board Practices and Processes}

Sample is 301 Indian private firms which responded to India CG Survey 2006. Number of missing or ambiguous responses ranges from 0 to 18 . Percentages are of firms with usable responses.

\begin{tabular}{|c|c|c|c|}
\hline Characteristic & Required & $\begin{array}{l}\text { Firms with } \\
\text { characteristic }\end{array}$ & $\begin{array}{c}\text { mean } \\
\text { (median) }\end{array}$ \\
\hline Director terms & $(1956)$ & & \\
\hline nonexecutive directors have staggered terms & & $275(91 \%)$ & \\
\hline executive directors have multiyear terms & & $261(92 \%)$ & \\
\hline \multicolumn{4}{|l|}{ Board meetings } \\
\hline Minimum of 4 physical meetings & $(2001)$ & $293(98 \%)$ & \\
\hline No. of physical meetings & & & $6.9(6)$ \\
\hline minutes prepared & $(1956)$ & $297(99 \%)$ & \\
\hline Dissents recorded in minutes & $(1956)$ & $211(75 \%)$ & \\
\hline \multicolumn{4}{|l|}{ Evaluation of CEO and other executives } \\
\hline regular system for evaluating $\mathrm{CEO}$ & & $151(51 \%)$ & \\
\hline regular system for evaluating other executives & & $248(83 \%)$ & \\
\hline succession plan for CEO & & $86(29 \%)$ & \\
\hline annual separate meeting for nonexecutive directors & & $46(15 \%)$ & \\
\hline board replaced CEO in last 5 years & & 0 & \\
\hline \multicolumn{4}{|l|}{ Evaluation of nonexecutive directors } \\
\hline regular system for evaluating nonexecutive directors & $\begin{array}{c}(2001) \\
\text { (recommended) }\end{array}$ & $76(25 \%)$ & \\
\hline retirement age for nonexecutive directors & & $44(15 \%)$ & \\
\hline $\begin{array}{l}\text { Director not renominated or resigned due to } \\
\text { performance or policy dispute during last } 5 \text { years }\end{array}$ & & 7 & \\
\hline \multicolumn{4}{|l|}{ Other } \\
\hline code of conduct & $(2004)$ & $275(91 \%)$ & \\
\hline policy restricting insider trading & & $278(92 \%)$ & \\
\hline $\begin{array}{l}\text { board members typically receive materials at least } \\
\text { one day in advance of meeting }\end{array}$ & & $291(96 \%)$ & \\
\hline regular director training & $\begin{array}{c}(2001) \\
\text { (recommended) }\end{array}$ & $30(13 \%)$ & \\
\hline
\end{tabular}

About half of Indian private firms report that they regularly evaluate the CEO; a larger number $(83 \%)$ evaluate other executives. One wonders, however, how rigorous these evaluations are, given that zero firms reported that the board had replaced the CEO in the last 5 years, and only three reported replacing other executives! Perhaps some CEOs were quietly encouraged to pursue other opportunities and the respondent did not know the circumstances under which a CEO left. Still, Indian CEOs do not appear to be at grave risk of losing their jobs for poor performance. We also asked about the existence of a CEO succession plan; only about $30 \%$ of respondents had one. Only 15\% held an annual board meeting solely for nonexecutive directors.

Clause 49 includes some recommended items. One is that firms evaluate the performance of nonexecutive directors. About one-quarter of responding firms report doing so. Only about 15\% of respondents had a retirement age for directors. There were occasional instances - a total of $7-$ in which a director was not renominated or resigned due to performance concerns or a policy dispute. Here too, reporting could be incomplete, or the respondent may not have known the reasons for board turnover. 
Clause 49 requires firms to adopt a code of conduct. About $90 \%$ of respondents have such a code; a similar number have a policy restricting insider trading. A full $96 \%$ normally provide materials to directors at least one day before board meetings. However, only $13 \%$ comply with the Clause 49 recommendation to provide regular director training.

\section{Audit Committee}

Clause 49 requires firms to have audit committees with at least three members, all nonexecutives, an independent chair, and at least one member with expertise in finance or accounting. The committee must meet at least four times per year. All but three responding firms have an audit committee. Of the firms with a committee, all but three (one) have the required number of members (a member with accounting or finance expertise).

Practice is less uniform on how audit committees operate. Only 65\% of respondents reported that the audit committee recommends reappointing or dismissing the external auditor, even though Clause 49 requires that the audit committee have this power. Seventy-nine percent have the required 4 meetings per year, but another 18\% report having three meetings; only 11 firms report 0 2 meetings. Only $68 \%$ of respondents have a bylaw to govern the audit committee, and at only $72 \%$ do the independent members meet separately at least once per year. One lone firm gives minority shareholders the power to appoint an audit committee member.

\section{Compensation of Executives and Nonexecutives}

Table 4 provides information on executive compensation and compensation disclosures. For most survey questions, complete responses were the norm, but not for compensation, either because respondents lacked the information or chose not to provide it. Executive compensation is modest by U.S. standards. The mean (median) CEO receives annual cash compensation of 64 (30) lakhs $\left(1\right.$ lakh $=10^{5}$ rupees $\approx$ US $\left.\$ 2,000\right)$. Only $16 \%$ of Indian private firms use stock options, which are the usual road to riches for U.S. executives. Most option grants are also modest. ${ }^{7}$

Indian law requires firms to obtain government approval to pay compensation above generally speaking -- the greater of (i) $5 \%$ of net profits for one manager and $10 \%$ for all managers; or (ii) if the firm doesn't meet the percentage of profits test, between Rs. 9 lakhs for small firms $(<1$ crore in book value of equity) and 24 lakhs for large firms ( $>100$ crores in book value of equity). Executive compensation under clause (ii) must also be approved by shareholders. Government approval to exceed these levels is usually obtainable, but the combination of these levels, desire to avoid seeking approval, and the need to obtain approval if over the threshold could all constrain executive pay. Seventeen percent of firms (52/301) obtained government approval.

Indian law requires companies to disclose the total pay of the $\mathrm{CEO}$ and each director. We asked firms about their disclosure, but cannot distinguish between "no" and missing responses. Most firms disclose CEO pay (95\%), but compliance is lower for the pay of other directors. Indian law requires shareholders to approve the pay of all directors as a group, but does not require separate approval of CEO pay. Oddly, 89\% of firms report that shareholders approve CEO pay, while only $70 \%$ report that shareholders approve the pay of all directors, even though the latter is the legal requirement.

7 A back-of-the-envelope estimate: The median grant to a CEO of 100,000 options might have an implied value $100,000 \mathrm{x}$ (typical $\$ 2$ share price) $\mathrm{x}(0.40$ estimate of option value/share price $)=\$ 80,000$. 


\section{Table 4. Executive and Director Compensation}

Sample is 301 Indian private firms which responded to India CG Survey 2006. Compensation is in lakhs $\left(1\right.$ lakh $=10^{5}$ rupees $\approx \$ 2,000$ ); options are in thousands of shares. For compensation, number of usable responses is shown. For disclosure and approval, we cannot distinguish between "no" and missing responses.

\begin{tabular}{|l|c|c|c|}
\hline Compensation & Required & Responses & mean (median) \\
\hline CEO cash compensation & & 251 & $64(30)$ \\
\hline Compensation of all other executives & & 184 & $2273(154)$ \\
\hline Executives receive stock options & & \multicolumn{2}{|l|}{$49 / 299(16 \%)$} \\
\hline Disclosure and Shareholder Approval & & Disclosed & Approved \\
\hline CEO total pay & $(1956)$ & $286(95 \%)$ & $267(89 \%)$ \\
\hline total pay of nonexecutive directors & $(1956) \&(2004)$ & $231(77 \%)$ & $183(61 \%)$ \\
\hline total pay of all directors & $(1956) \&(2001)$ & $267(89 \%)$ & $211(70 \%)$ \\
\hline
\end{tabular}

\section{E. External Auditor}

We also asked about auditor independence. The external auditor provides non-audit services at about half of the firms. When the auditor provides non-audit services, mean (median) fees for non-audit services are 18\% (10\%) of the auditor's total fees.

Indian law does not require rotation of audit firms, or the engagement partner within an audit firm. Nonetheless, almost half of firms report that their audit firm rotates the partner responsible for their account every 5 years. Auditor dismissal is rare -- only 2 firms noted dismissals in the last 5 years. One firm said the reason was fees charged, the other did not provide a reason.

\section{F. Shareholder Rights}

Table 5 summarizes questions related to shareholder rights. Indian law has required companies to allow postal ballots since 1956, yet only $73 \%$ do so. Given that most firms have a controlling shareholder, the fraction of shares voted at the most recent annual shareholder is surprisingly small, at a mean of only 58\%. This suggests that minority shareholders often do not vote. Yet shareholder resolutions are not uncommon. About one-sixth of firms had one or more resolutions proposed in the last 5 years.

Indian law provides takeout rights on a sale of control, which require the new controller to offer to buy all shares at the price paid for the controlling shares. We asked whether minority shareholders receive takeout rights, but only 21 firms (8\%) reported providing these rights. Possible explanations include poor phrasing (we asked whether the firm, rather than the new controller, provides the rights), or ignorance of this requirement. The famously slow Indian judicial system limits the effectiveness of shareholder remedies. A modest number of firms (20 firms, 7\%) have responded to problems with the courts by providing for disputes with shareholders to be resolved by arbitration.

Under Indian law, shareholders holding 10\% of a company's shares can demand that the company hold a special shareholder meeting. This happened at 14 firms $(5 \%)$ during the last five years. Shareholders can also asked SEBI or a special appellate court, the Companies Appellate Tribunal, to investigate oppression by the controlling shareholder, but only one firm reported facing 
such an investigation in the last five years. Finally, only one firm has issued preferred shares. Thus, Indian firms are not using these shares to avoid the one common share, one vote regime. ${ }^{8}$

\section{Table 5. Shareholder Rights}

Table shows promoter ownership for non-bank Indian private firms (\% of responding firms). Sample is 301 firms which responded to India CG Survey 2006 and have ownership data on Prowess. Number of missing or ambiguous responses ranges from 1 to 31. Percentages are of firms with usable responses.

\begin{tabular}{|l|c|c|c|}
\hline Characteristic & Required & $\begin{array}{c}\text { Firms with } \\
\text { characteristic }\end{array}$ & $\begin{array}{c}\text { mean } \\
\text { (median) }\end{array}$ \\
\hline shareholders can vote by postal ballot & $(1956)$ & $218(73 \%)$ & \\
\hline percentage of shares voted at most recent AGM & & & $58 \%(60 \%)$ \\
\hline company had shareholder resolution in last 5 years & & $52(17 \%)$ & \\
\hline disputes w. shareholders resolved by arbitration & & $20(7 \%)$ & \\
\hline $\begin{array}{l}\text { shareholders requested extraordinary meeting in last } \\
5 \text { years }\end{array}$ & & $14(5 \%)$ & \\
\hline $\begin{array}{l}\text { shareholders asked SEBI or Tribunal to investigate } \\
\text { oppression within last 5 years }\end{array}$ & & 1 & \\
\hline company has preferred shares & & 1 & \\
\hline
\end{tabular}

\section{G. Related Party Transactions}

Related party transactions and other forms of self-dealing by controlling shareholders are a significant concern in India. Most Indian firms have a major, often controlling shareholder. Bertrand, Mehta and Mullainathan (2002) report evidence of tunneling within Indian business groups. The good news is that $78 \%$ of the responding firms have policies requiring RPTs to be on arms-length terms. The less good news is that there are lots of RPTs. Clause 49 requires the audit committee to approve all RPTs and requires the firm to disclose "materially significant" RPTs to shareholders. Ninety-four percent of firms said they reported RPTs to shareholders, but this includes some firms which reported having no or negligible RPTs, and thus nothing to disclose. When asked to quantify RPTs as a percentage of sales, 67\% (20\%) of firms with RPTs reported were at least $1 \%(5 \%)$ of revenue. Sixty percent of firms reported that their board reviewed at least one RPT in the last year; $36 \%$ reported board review of five or more transactions.

It is one thing to require RPTs to be on arms-length terms, but another to put procedures in place to ensure that the policy is adhered to. Table 6 summarizes approval requirements, separately for RPTs with an inside director and with a controller. Approval by non-conflicted directors is uncommon $(7-9 \%$ of firms require this) and approval by non-conflicted shareholders is rare $(1 \%)$. Thus, approval can often be influenced, and not infrequently dictated, by a controller.

8 Compare Brazil, where many firms issue preferred shares, which are in substance nonvoting common shares, to ensure that the control group retains control. See Black, de Carvalho and Gorga (2010b). 


\section{Table 6. Approval Requirements for Related Party Transactions}

Sample is 301 Indian private firms which responded to India CG Survey 2006. We cannot distinguish between "no" and missing responses.

\begin{tabular}{|l|c|c|}
\hline \multirow{2}{*}{$\begin{array}{l}\text { Related Party Transaction Approval } \\
\text { Requirements }\end{array}$} & \multicolumn{2}{|c|}{ Transaction with } \\
\cline { 2 - 3 } & $\begin{array}{c}\text { with inside } \\
\text { director }\end{array}$ & $\begin{array}{c}\text { with controlling } \\
\text { shareholder }\end{array}$ \\
\hline no specific requirement & $81(27 \%)$ & $102(34 \%)$ \\
\hline approval by audit committee & $96(32 \%)$ & $82(27 \%)$ \\
\hline approval by board of directors & $212(70 \%)$ & $182(61 \%)$ \\
\hline approval by shareholders & $37(12 \%)$ & $44(15 \%)$ \\
\hline approval by non-conflicted directors & $26(9 \%)$ & $20(7 \%)$ \\
\hline approval by non-conflicted shareholders & $2(1 \%)$ & $3(1 \%)$ \\
\hline
\end{tabular}

\section{H. Cross-Listing and Financial Disclosure}

Table 7 summarizes information on cross-listing and financial disclosure. Cross-listing may, depending on the destination exchange, require the firm to provide additional disclosures. Twentytwo firms $(7 \%)$ are cross-listed, some on more than one non-Indian exchange. ${ }^{9}$ However, only four firms are cross-listed on US exchanges (in the US on levels 2 or 3 -- four firms on the New York Stock Exchange and none on NASDAQ -- and hence are subject to U.S. reporting requirements and the U.S. Sarbanes-Oxley Act.. The rest cross-list on European markets or in the U.S. over-thecounter market, where they face few disclosure requirements (Doidge, Karolyi and Stulz, 2009). Only about $7 \%$ of firms prepare financial statements that meet U.S. GAAP or International Financial Reporting Standards (IFRS).

\section{Table 7. Financial Disclosure}

Table shows number of Indian private firms ( $\%$ of responding firms) with a positive response to the indicated $i$ th items. Sample is 301 Indian private firms which responded to India CG Survey 2006.

\begin{tabular}{|c|c|c|}
\hline Question & Yes & $\%$ Yes \\
\hline Company has shares cross-listed in another country & 22 & $7 \%$ \\
\hline \multicolumn{3}{|l|}{ If yes, which country: } \\
\hline $\mathrm{UK}$ & 12 & \\
\hline Luxembourg & 11 & \\
\hline Germany (Frankfurt or Berlin) & 10 & \\
\hline U.S. - off exchange & 6 & \\
\hline U.S. - New York Stock Exchange or NASDAQ & 4 & \\
\hline Company provides IFRS or U.S. GAAPfinancial statements & 20 & $6.8 \%$ \\
\hline
\end{tabular}

Neither SEBI nor the stock exchanges maintains a website containing annual reports or financial statements for all listed firms. Thus, firm websites are an important way that investors can obtain this information. Table 8 summarizes what firms provide. About 67\% provide annual financial statements on their website. About half also post the annual report to shareholders; a similar number provide press releases. About 43\% post a notice of an upcoming shareholder opinion, but nary a firm announces the meeting results. Finally, $6 \%$ have no website (or have one that we could not find).

\footnotetext{
9 Cross-listing data was provided to us by Kate Litvak (see Litvak, 2007).
} 
Law \& Economics W orking Papers, Art. 10 [2010]

\section{Table 8. Information on Company Website}

Sample is 301 Indian private firms which responded to India CG Survey 2006. Number of responses varies from 276 to 278. Percentages are of firms with usable responses.

\begin{tabular}{|l|c|c|}
\hline Information Item & Yes & $\%$ Yes \\
\hline \hline Financial information & 182 & $67 \%$ \\
\hline annual financial statements & 137 & $50 \%$ \\
\hline annual report to shareholders & 145 & $54 \%$ \\
\hline share price information & 154 & $57 \%$ \\
\hline press releases & 137 & $46 \%$ \\
\hline notice of upcoming shareholder meetings & 0 & $0 \%$ \\
\hline results of shareholder meetings & 18 & $6 \%$ \\
\hline Website not located & & \\
\hline
\end{tabular}

\section{Since When?}

We asked firms how long selected governance practices had been in place. Table 9 summarizes the responses. Many governance practices were adopted recently -- especially those which recently became legally required. -- such as having a written code of conduct for directors and executives, which became mandatory in 2004. Similarly, policies on insider trading, on recommendation of the external auditor by the audit committee, and RPT disclosure are mostly of recent vintage. Use of stock options is recent as well; only 9 firms used them before 2000.

In contrast, the practice of separating the positions of $\mathrm{CEO}$ and chairman has a long vintage. Its current use may partly reflect the Clause 49 rules, under which a firm is permitted to have at least $33 \%$ independent directors if these positions are separated, versus 50\% otherwise. But many firms voluntarily separate the two posts, including firms that separated them before Clause 49 was adopted, and the 114 firms that have both separation and 50\% independent directors (see Table 2).

\section{Table 9. Since When Has a Practice Existed}

Sample is 301 Indian private firms which responded to India CG Survey 2006. For some questions, number of usable responses may not sum to firms with practice because some firms did not answer the "since when" question.

\begin{tabular}{|l|c|c|c|c|c|}
\hline & & & \multicolumn{3}{|c|}{ Since When } \\
\hline Practice & $\begin{array}{c}\text { Usable } \\
\text { responses }\end{array}$ & Required & 2000s & 1990s & Earlier \\
\hline When was company incorporated & 298 & & 6 & 83 & 209 \\
\hline Firm has separate CEO and chairman & 163 & & 46 & 57 & 60 \\
\hline Firm has system for evaluating CEO & 137 & & 71 & 43 & 23 \\
\hline Firm has code of conduct & 266 & $(2004)$ & 246 & 13 & 7 \\
\hline policy restricting insider trading & 251 & & 218 & 37 & 6 \\
\hline audit committee recommends auditor & 180 & $(2001)$ & 149 & 24 & 7 \\
\hline executives receive stock options & 48 & & 39 & 7 & 2 \\
\hline RPTs must be on arms-length terms & 185 & & 111 & 31 & 43 \\
\hline Material RPTs are disclosed to shareholders & 224 & $(2001)$ & 170 & 31 & 23 \\
\hline
\end{tabular}

\section{J. Government Enforcement}

In some countries, company law is enforced privately or not at all. In the U.S., for example, the Securities and Exchange Commission enforces securities law, but Delaware corporate law is 
enforced only privately, through suits by shareholders, creditors, or the company itself. The Indian government, in contrast, has a variety of powers under corporate law, including the compensation limits noted above, as well as the power to provide relief for oppression or mismanagement, remove management, demand a special audit, inspect the company's accounts, and impose fines for some company law violations.

These powers, however, are rarely exercised. In the last 5 years the government has removed a director or blocked a director from serving at one Indian private firm and one foreigncontrolled firm in our sample, dismissed an executive at one government firm, and ordered a special audit at three private firms. To be sure, powers that are rarely exercised can still be deterrents.

\section{Is Corporate Governance Associated with Firm Value?}

We turn next to the association between firm-level governance practices and market value. We limit the sample to 276 non-bank Indian private firms with data available on Tobin's $q$. We construct a broad Indian corporate governance index, and ask whether the index or subindices predicts market values. We use $\ln$ (Tobin's $q$ ) as our principal measure of market value (we take logs to address high- $q$ outliers), and market/book and market/sales in robustness checks.

Some caveats. The analysis below uses only cross-sectional data. Moreover, governance and other firm characteristics could be endogenously determined. We have no instrument for governance, so make no claims as to causation. Also, firm market values reflect trading prices for noncontrolling shares, and does not capture any additional value enjoyed by controlling shareholders. Governance changes could produce market value gains for outside investors by increasing overall firm value, by reducing the private benefits of control enjoyed by insiders (thus transferring value from insiders to outsiders), or both. We cannot distinguish here between these two broad channels. We discuss in Part VI the extent to which our results might generalize to other emerging markets.

\section{A. Non-governance Variables and Descriptive Statistics}

Table 10 defines the principal financial and other non-governance variables used in this paper, and provides summary statistics. This data comes principally from Prowess, which is the principal source of financial information for Indian firms, analogous to a combination of Compustat and CRSP for U.S. firms. 
Table 10. Non-Governance Variables

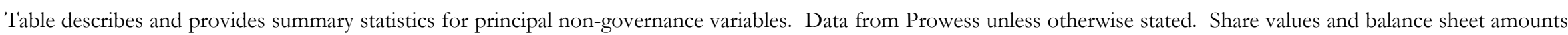

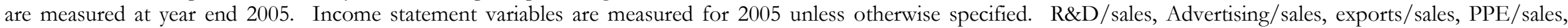
CAPEX/sales and EBDIT/sales are assumed to be zero if missing (7-15 firms depending on measure). Number of observations varies from 276 to 296 . Amounts in crores.

\begin{tabular}{|c|c|c|c|c|c|c|}
\hline Variables & Description & Mean & Median & $\begin{array}{c}\text { Standard } \\
\text { Deviation }\end{array}$ & Minimum & Maximum \\
\hline Tobin’s $q$ & $\begin{array}{l}\text { Estimated [book value of debt }+ \text { book value of preferred stock }+ \\
\text { market value of common stock]/book value of assets. }\end{array}$ & 2.26 & 1.54 & 1.73 & 0.32 & 13.88 \\
\hline Market-to-Book Ratio & $\begin{array}{l}\text { Market value/book value of common stock. We drop } 17 \text { firms with } \\
\text { negative, zero or missing book value of common stock. }\end{array}$ & 3.21 & 2.20 & 9.32 & 0 & 149.53 \\
\hline Book Value of Assets & Book value of assets. & 905 & 199 & 3,134 & 9.01 & 42,545 \\
\hline Market Value of Equity & Market value of common stock plus book value of preferred stock. & 1,954 & 261 & 7,961 & 3.5 & 81,737 \\
\hline Debt/Equity & Book value of debt divided by market value of common stock. & 1.18 & 0.72 & 1.97 & 0 & 19.46 \\
\hline Debt/Assets & Book value of debt divided by book value of total assets & 1.34 & 0.66 & 2.67 & 0 & 36.21 \\
\hline Years Listed & Number of years since original listing. & 29.72 & 21 & 22.34 & 3 & 126 \\
\hline Sales Growth & Geometric growth rate from 2003 to 2005 (or available period). & 0.35 & 0.17 & 1.46 & -0.39 & 21.32 \\
\hline R\&D/Sales & Research and development (R\&D) expense/sales. & 0.002 & 0 & 0.013 & 0 & 0.17 \\
\hline Advertising/Sales & Ratio of advertising expense to sales. & 0.009 & 0 & 0.022 & 0 & 0.18 \\
\hline Exports/Sales & Ratio of export revenue to sales. & 0.232 & 0.07 & 0.31 & 0 & 1.02 \\
\hline PPE/Sales & Ratio of property, plant and equipment to sales. & 0.65 & 0.40 & 0.95 & 0.004 & 9.89 \\
\hline Capex/Sales & Ratio of capital expenditures to sales. & 1.19 & 0.62 & 2.58 & 0.044 & 36.59 \\
\hline EBDIT/Sales & Ratio of earnings before income and taxes to sales. & 0.18 & 0.15 & 0.82 & -11.71 & 5.99 \\
\hline Share Turnover & $\begin{array}{l}\text { Average daily shares traded during } 2005 / \text { shares held by public } \\
\text { shareholders }\end{array}$ & 0.007 & 0.0023 & 0.017 & 0.00001 & 0.15 \\
\hline Foreign Ownership & $\begin{array}{l}\text { Foreign ownership of the firm's common shares divided by } \\
\text { common shares outstanding. }\end{array}$ & 8.38 & 2.92 & 12.29 & 0 & 66.02 \\
\hline Market Share & Firm's share of sales by all firms in same 4-digit industry. & 0.02 & 0.005 & 0.056 & 0 & 0.44 \\
\hline Cross-Listing Dummy & 1 if firm is cross-listed on a foreign exchange. & 0.08 & 0 & 0.27 & 0 & 1 \\
\hline Promoter Ownership & Percentage share ownership by promoters. & 49.11 & 49.78 & 18.47 & 0 & 98.19 \\
\hline Business Group Dummy & 1 if a member of a business group, 0 otherwise. & 0.53 & 1 & 0.50 & 0 & 1 \\
\hline MSCI Dummy & $\begin{array}{l}1 \text { if firm included in Morgan Stanley Capital International Index at } \\
\text { year-end 2004, } 0 \text { otherwise. Source: MSCI. }\end{array}$ & 0.03 & 0 & 0.17 & 0 & 1 \\
\hline Industry Dummies & \multicolumn{6}{|c|}{10 industry groups, plus "other" category. Constructed using information from Prowess and company websites. } \\
\hline
\end{tabular}


Balasubramanian et al::

\section{B. Construction of the Indian Corporate Governance Index}

We rely on the survey and firm annual reports to construct an India Corporate Governance Index (ICGI). We identify 49 firm attributes that are often believed to correspond to "good" governance, on which we have reasonably complete data, reasonable variation across firms, and sufficient difference from another element included in ICGI. Manifestly, there is judgment involved on which elements to include. Each is coded " 1 " if a firm has the attribute; "0" otherwise. We group these elements into indices as follows:

- Board Structure (with subindices for board independence and board committees)

- Disclosure (with subindices for disclosure substance and for auditor independence)

- Related Party Transactions (subindices for volume of RPTs and approval procedures)

- Shareholder Rights

- Board Procedure (with subindices for overall procedure and for audit committee procedure)

Table 11 describes the index components. Within each index, we give equal weight to each element. We normalize each index to mean 0 and standard deviation 1, and sum the normalized index scores to obtain an overall ICGI score. If a firm has a missing value for a particular element, we use its average score for the nonmissing values to compute each index. ${ }^{10}$

\section{Table 11. Corporate Governance Index: Elements and Summary Statistics}

Description and summary statistics for elements included in India Corporate Governance Index (ICGI), for 296 private, non-bank Indian firms which responded to India CG Survey 2006. All variables are coded yes=1, no=0. In "responses" column, numerator is number of " 1 " responses, denominator is total number of responses.

\begin{tabular}{|c|c|c|c|c|}
\hline Label & Variable & Responses & Mean & \% Responding \\
\hline \multicolumn{5}{|c|}{ Board Structure Index } \\
\hline \multicolumn{5}{|c|}{ Board independence subindex } \\
\hline BdIn.1 & Board contains of at least $50 \%$ independent directors & $205 / 290$ & 0.71 & $98 \%$ \\
\hline BdIn.2 & Board contains over $50 \%$ independent directors & $135 / 290$ & 0.47 & $98 \%$ \\
\hline BdIn.3 & CEO is NOT chairman of the board & $175 / 296$ & 0.59 & $100 \%$ \\
\hline BdIn.4 & $\begin{array}{l}\text { Compliance with Clause 49: Either (i) board consists of at } \\
\text { least } 50 \% \text { independent directors or (ii) board consists of at } \\
\text { least } 1 / 3 \text { independent directors and CEO is not chairman }\end{array}$ & $253 / 290$ & 0.87 & $98 \%$ \\
\hline \multicolumn{5}{|c|}{ Board committee subindex } \\
\hline $\mathrm{BdCm} .1$ & Audit committee exists, has majority of indep. directors & $268 / 284$ & 0.94 & $96 \%$ \\
\hline $\mathrm{BdCm} .2$ & Compensation committee exists. & $213 / 296$ & 0.72 & $100 \%$ \\
\hline \multicolumn{5}{|c|}{ Disclosure Index } \\
\hline \multicolumn{5}{|c|}{ Disclosure substance subindex } \\
\hline Di.1 & Related party transactions are disclosed to shareholders & $270 / 287$ & 0.94 & $97 \%$ \\
\hline Di.2 & Firm has regular meetings with analysts & $185 / 296$ & 0.63 & $100 \%$ \\
\hline Di.3 & Firm discloses direct and indirect $5 \%$ holders & $216 / 294$ & 0.73 & $99 \%$ \\
\hline Di.4 & $\begin{array}{l}\text { No shareholder agreement among controlling shareholders, } \\
\text { or agreement exists and is disclosed. }\end{array}$ & $264 / 270$ & 0.98 & $91 \%$ \\
\hline Di.5 & Firm puts annual financial statements on web & $182 / 271$ & 0.67 & $92 \%$ \\
\hline
\end{tabular}

10 For Board Independence subindex, three of the four elements require data on number of independent directors, which is missing for 6 firms. We judged that multiplying these firms' scores on the remaining element (CEO $\neq$ chairman) by 4 would overweight to this element, so multiplied by 2 instead. Five of these 6 firms had $\mathrm{CEO} \neq$ chairman. 


\begin{tabular}{|c|c|c|c|c|}
\hline Label & Variable & Responses & Mean & $\%$ Responding \\
\hline Di.6 & Firm puts quarterly financial statements on web & $198 / 271$ & 0.73 & $92 \%$ \\
\hline Di.7 & Firm puts annual report on web & $137 / 273$ & 0.50 & $92 \%$ \\
\hline Di.8 & Firms puts directors' report on web & $143 / 273$ & 0.52 & $92 \%$ \\
\hline Di.9 & Firm puts corporate governance report on web & $148 / 273$ & 0.54 & $92 \%$ \\
\hline \multicolumn{5}{|c|}{ Auditor independence (disclosure reliability) subindex } \\
\hline Dr.1 & Auditor does not provide non-audit services & $151 / 296$ & 0.51 & $100 \%$ \\
\hline Dr.2 & $\begin{array}{l}\text { Auditor does not provide non-audit services or non-audit } \\
\text { fees are }<25 \% \text { of total auditor fees }\end{array}$ & $185 / 296$ & 0.63 & $100 \%$ \\
\hline Dr.3 & Full board reviews auditor's recommendations & $275 / 290$ & 0.95 & $98 \%$ \\
\hline Dr.4 & Audit partner is rotated every 5 years & $120 / 282$ & 0.43 & $95 \%$ \\
\hline \multicolumn{5}{|c|}{ Related Party Index } \\
\hline \multicolumn{5}{|c|}{$R P T$ volume subindex } \\
\hline Re.1 & Firm does not have loans to insiders & $273 / 291$ & 0.94 & $98 \%$ \\
\hline Re.2 & $\begin{array}{l}\text { Firm does not have significant sales to or purchases from } \\
\text { insiders }\end{array}$ & $270 / 291$ & 0.93 & $98 \%$ \\
\hline Re.3 & Firm does not rent real property from or to an insider & $233 / 291$ & 0.80 & $98 \%$ \\
\hline Re.4 & Firm had negligible revenue from RPTs ( $0-1 \%$ of sales) & $139 / 209$ & 0.67 & $71 \%$ \\
\hline Re.5 & $\begin{array}{l}\text { No RPTs brought to board or audit committee for approval } \\
\text { in last } 3 \text { years }\end{array}$ & $69 / 175$ & 0.39 & $59 \%$ \\
\hline Re.6 & RPTs are on arms-length terms & $226 / 289$ & 0.78 & $98 \%$ \\
\hline \multicolumn{5}{|c|}{ RPT approval subindex } \\
\hline Ra.1 & $\begin{array}{l}\text { RPTs with executives approved by board, audit committee or } \\
\text { shareholders }\end{array}$ & $219 / 296$ & 0.74 & $100 \%$ \\
\hline Ra.2 & $\begin{array}{l}\text { RPTs with executives approved by audit committee or non- } \\
\text { interested directors }\end{array}$ & $97 / 296$ & 0.33 & $100 \%$ \\
\hline Ra.3 & Shareholder approval of RPTs with executives & $37 / 296$ & 0.13 & $100 \%$ \\
\hline Ra.4 & $\begin{array}{l}\text { RPTs with controlling shareholder approved by board, audit } \\
\text { committee or shareholders }\end{array}$ & $197 / 296$ & 0.66 & $100 \%$ \\
\hline Ra.5 & $\begin{array}{l}\text { RPTs with controlling sharebolder approved by audit committee } \\
\text { or non-interested directors }\end{array}$ & $84 / 296$ & 0.28 & $100 \%$ \\
\hline \multicolumn{5}{|c|}{ Shareholder Rights Index } \\
\hline Sh.1 & Directors serve one year terms & $26 / 296$ & 0.09 & $100 \%$ \\
\hline Sh.2 & Firm allows voting by postal ballot & $213 / 292$ & 0.73 & $99 \%$ \\
\hline Sh.3 & Disputes with shareholders are subject to arbitration & $20 / 266$ & 0.08 & $90 \%$ \\
\hline Sh.4 & Company has policy against insider trading & $273 / 295$ & 0.93 & $99 \%$ \\
\hline Sh.5 & Board has one or more minority shareholder representatives & $3 / 294$ & 0.01 & $99 \%$ \\
\hline \multicolumn{5}{|c|}{ Board Procedure Index } \\
\hline \multicolumn{5}{|c|}{ Overall procedure subindex } \\
\hline Pr.1 & Average board meeting attendance rate $\geq 80 \%$ & $174 / 296$ & 0.59 & $100 \%$ \\
\hline Pr.2 & Firm has system to evaluate $\mathrm{CEO}$ & $146 / 293$ & 0.50 & $99 \%$ \\
\hline $\operatorname{Pr} .3$ & Firm has system to evaluate other executives & $243 / 293$ & 0.83 & $99 \%$ \\
\hline Pr.4 & Firm has system to evaluate nonexecutive directors & $74 / 292$ & 0.25 & $99 \%$ \\
\hline Pr.5 & Firm has succession plan for CEO & $84 / 288$ & 0.29 & $97 \%$ \\
\hline Pr.6 & Firm has retirement age for nonexecutive directors & $41 / 294$ & 0.14 & $99 \%$ \\
\hline Pr.7 & Directors receive regular board training & $39 / 294$ & 0.13 & $99 \%$ \\
\hline Pr. 8 & Firm has annual board meeting only for nonexecutives & $46 / 292$ & 0.16 & $99 \%$ \\
\hline Pr.9 & Board receives materials in advance & $285 / 296$ & 0.96 & $100 \%$ \\
\hline Pr.10 & Nonexecutives can hire own counsel and advisors & $172 / 292$ & 0.59 & $99 \%$ \\
\hline Pr.11 & Firm has code of ethics & $269 / 296$ & 0.91 & $100 \%$ \\
\hline \multicolumn{5}{|c|}{ Audit committee procedure subindex } \\
\hline Pa.1 & Firm has bylaws governing audit committee & $199 / 293$ & 0.68 & $99 \%$ \\
\hline $\mathrm{Pa} .2$ & Audit committee recommends external auditor & $191 / 293$ & 0.65 & $99 \%$ \\
\hline Pa.3 & Independent members of committee meet separately & $212 / 292$ & 0.73 & $99 \%$ \\
\hline
\end{tabular}


Figure 1 shows the overall variation in the index. One firm with a very low score aside, the distribution of ICGI is reasonably symmetric and close to normal.

\section{Figure 1. Distribution of $I C G I$}

Fraction of firms with ICGI scores in indicated ranges, plus superimposed normal probability density function. Sample $=296$ private, non-bank Indian firms. Mean $=0$ (by construction), median $=0.211 ; \sigma=2.71$.

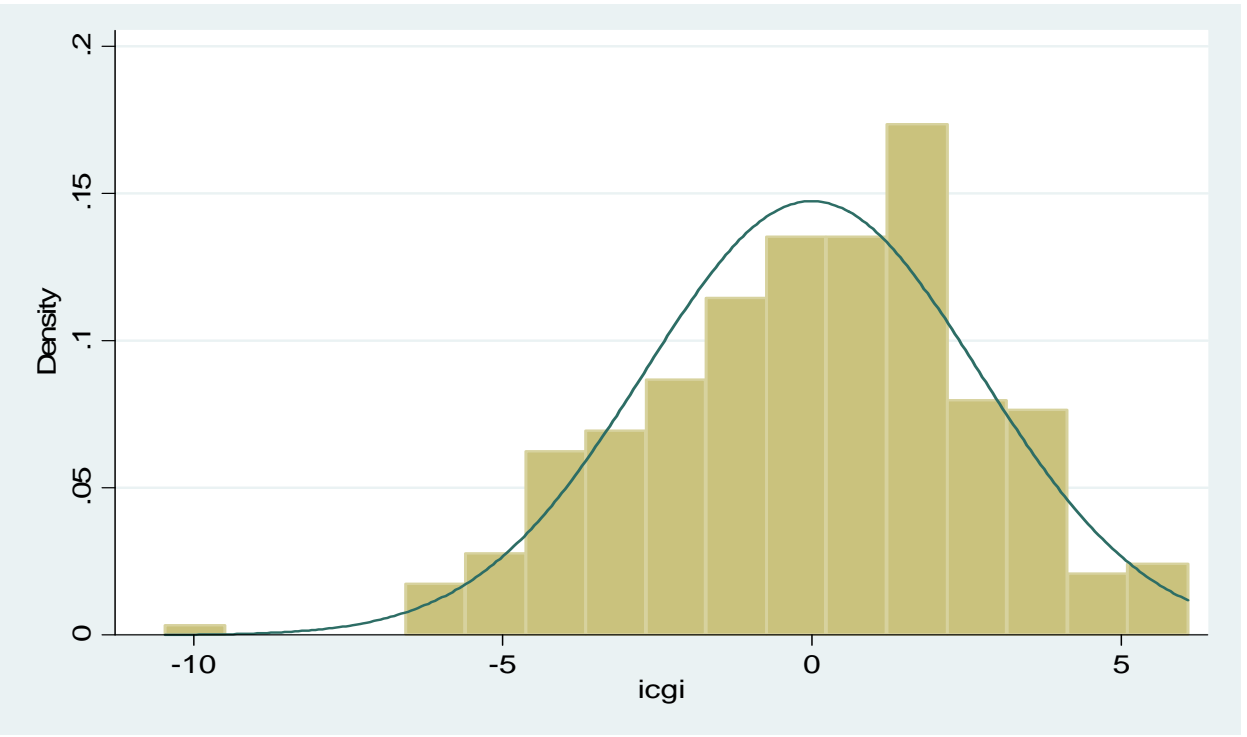

Table 12, Panel A provides summary statistics on ICGI and its components; Panel B provides a correlation table. There is substantial spread on each index and subindex, and for ICGI as a whole. The mean (median) firm has " 1 " values for 27.5 (27.8) elements. The inter-index correlations are generally positive but modest, so there is only limited colinearity between indices.

\section{Table 12. Summary Data for ICGI}

Panel A. Descriptive statistics for ICGI and components (before normalizing), for 296 private, non-bank Indian firms which responded to India CG Survey 2006.

\begin{tabular}{|lccccc|}
\hline & Mean & $\begin{array}{c}\text { Stand. } \\
\text { Dev. }\end{array}$ & Min. & Max. & $\begin{array}{c}\text { Max } \\
\text { possible }\end{array}$ \\
\hline Board Structure Index & 4.29 & 1.36 & 0 & 6 & 6 \\
$\quad$ Board Independence & 2.61 & 1.19 & 0 & 4 & 4 \\
Board Committees & 1.64 & 0.57 & 0 & 2 & 2 \\
Disclosure Index & 8.85 & 2.65 & 0 & 13 & 13 \\
$\quad$ Disclosure Substance & 6.20 & 2.41 & 0 & 9 & 9 \\
$\quad$ Disclosure Reliability & 2.65 & 0.89 & 0 & 4 & 4 \\
Related Party Index & 6.66 & 2.11 & 0 & 11 & 11 \\
$\quad$ Level of Related Party Transactions & 4.67 & 1.24 & 0 & 6 & 6 \\
$\quad$ Transaction Approval & 2.14 & 1.55 & 0 & 5 & 5 \\
Shareholder Rights Index & 2.23 & 0.81 & 0 & 4.8 & 5 \\
Procedure Index & 7.43 & 2.41 & 1 & 14 & 14 \\
$\quad$ Board Procedure & 5.37 & 1.95 & 0 & 11 & 11 \\
$\quad$ Audit Committee Procedure & 2.04 & 0.90 & 0 & 3 & 3 \\
\hline Non-normalized sum of ICGI components & 27.47 & 4.83 & 9.0 & 38.4 & 49 \\
\hline ICGI (sum of normalized subindices) & 0 & 2.71 & -10.46 & 6.07 & \\
\hline
\end{tabular}


Panel B. Correlations among ICGI and its components. ** and *** indicate significance at 5\% and 1\% levels. Statistically significant correlations (at $5 \%$ level or better) are shown in boldface.

\begin{tabular}{|lcccccc|}
\hline & ICGI & $\begin{array}{c}\text { ICGI - } \\
\text { indicated } \\
\text { index }\end{array}$ & $\begin{array}{c}\text { Board } \\
\text { Structure }\end{array}$ & Disclosure & $\begin{array}{c}\text { Related } \\
\text { Party }\end{array}$ & $\begin{array}{c}\text { Shareholder } \\
\text { Rights }\end{array}$ \\
\hline ICGI & 1 & & & & & \\
Board Structure Index & $\mathbf{0 . 5 4 * * *}$ & $\mathbf{0 . 2 0} * * *$ & 1 & & & \\
Disclosure Index & $\mathbf{0 . 5 6 * * *}$ & $\mathbf{0 . 2 2} * * *$ & $\mathbf{0 . 2 1 * * *}$ & 1 & & \\
Related Party Index & $\mathbf{0 . 5 3 * * *}$ & $\mathbf{0 . 1 9 * * *}$ & 0.089 & $\mathbf{0 . 1 5 * * *}$ & 1 & 1 \\
Shareholder Rights Index & $\mathbf{0 . 4 6 * * *}$ & $\mathbf{0 . 1 0} * * *$ & 0.044 & -0.043 & 0.060 & 1 \\
Board Procedure Index & $\mathbf{0 . 6 1 * * *}$ & $\mathbf{0 . 2 9} * * *$ & $\mathbf{0 . 1 2 * *}$ & $\mathbf{0 . 1 9 * * *}$ & $\mathbf{0 . 1 5 * *}$ & $\mathbf{0 . 1 8 * * *}$ \\
\hline
\end{tabular}

\section{Univariate Association Between Governance and Firm Value}

We next assess the association between ICGI and its components, on one hand, and firms' market values, on the other. Figure 2 provides a scatter plot of ICGI against Tobin's $q$ at year-end 2005 (shortly before we conducted the survey), plus a regression line from a regression of Tobin's $q$ on ICGI plus a constant term. There is a visually apparent correlation; the simple correlation is 0.26 and the regression coefficient is $0.064(t=4.90)$.

We have 276 firms with data on Tobin's q. In Figure 2 and later regressions we drop 12 outlier observations, for which a studentized residual from regressing Tobin's $q$ on ICGI is greater than \pm 1.96 . This generates a regression sample of 264 firms.

\section{Figure 2. ICGI (Indian Corporate Governance Index) and Tobin's $\boldsymbol{q}$}

Scatter plot of ICGI versus Tobin's $q$ at year-end 2005 for 264 firms with data on Tobin's $q$ which responded to India CG Survey 2006, after dropping 12 outlier observations based on |studentized residual| from regression of $\ln (q)$ on ICGI $>1.96$. Highest and lowest $5 \%$ of Tobin's $q$ values are included in regression but suppressed in the scatter plot for better visual presentation. Regression coefficient $=0.064(t=4.90)$.

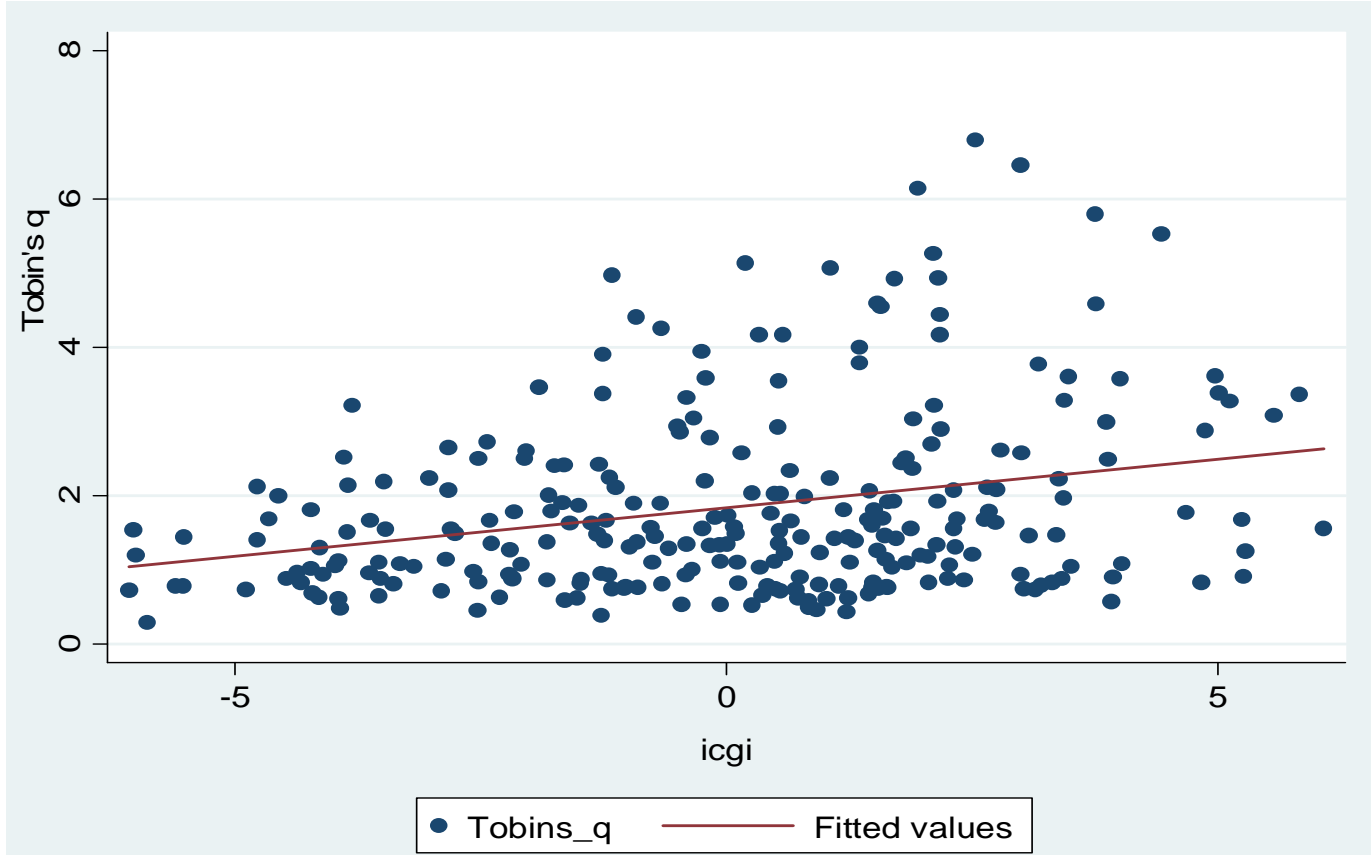




\section{Association Between Governance and Market Value: Full Sample Results}

In Table 13, regressions (1)-(3) we regress $\ln$ (Tobin's q) against ICGI and control variables. In unreported robustness checks, we obtain similar results if we do not drop outliers or keep them but winsorize $\ln (q)$ at $5 \%$ and $95 \%$. Regressions (4)-(5) report robustness checks with $\ln$ (market/book) and $\ln$ (market/sales) as dependent variables.

Many firm characteristics can be associated with both Tobin's $q$ and governance. We therefore include a broad array of control variables, to limit omitted variable bias. We use $\ln$ (assets) to control for the effect of firm size on Tobin's $q$. In unreported robustness checks, we obtain similar results using $\ln$ (sales). We include $\ln$ (years listed) as a proxy for firm age, because younger firms are likely to be faster-growing and perhaps more intangible asset-intensive, which can lead to higher Tobin's q. We include leverage (debt/market value of common equity) because it can influence Tobin's $q$ by reducing free cash flow problems.

We control for firms' growth prospects using geometric average sales growth over 20032005, for capital intensity using (PPE/sales, and for capital expenditures relative to the historical capital stock (capex/PPE). We control for intangible assets using (R\&D expense)/sales and (advertising expense)/sales. Because export-oriented firms may be different than other firms, we control for exports/sales. We control for profitability measured by EBDIT/sales. We control for market share in 4-digit industry because it could affect both profitability and product market constraints. We include share turnover (traded shares as a percentage of public float) as a measure of liquidity, since share prices may be higher for firms with more easily traded shares. We include promoter ownership as a measure of insider ownership. We include foreign ownership because foreign investors are diversified and may be willing to pay higher prices than domestic investors, thus affecting Tobin's $q$, may pressure firms to improve their governance, or may invest in better governed firms (Ferreira and Matos, 2007). Since both governance and Tobin's $q$ may reflect industry factors, we include industry dummies. ${ }^{11}$ We include a business group dummy because business group firms may have political connections, access to financing, or be more diversified, which could affect Tobin's $q$ (Zattoni, Pedersen and Kumar, 2009; Singh and Gaur, 2009). We include a cross-listing dummy, which can proxy for foreign investor interest, liquidity, and enhanced disclosure, and a dummy variable for a firm's inclusion in the Morgan Stanley Capital International Index for East Asia, which may proxy for liquidity and price pressure due to index fund purchases.

In regression (1), the only independent variables are ICGI and industry dummies. Including these dummies reduces the coefficient on ICGI from 0.064 (Figure 1) to 0.057 . As we add additional control variables in regressions (2) and (3), the coefficient on ICGI declines to 0.034, indicating the importance of a good set of control variables. However, ICGI remains statistically significant $(t=2.75)$ and economically meaningful. A one standard deviation (2.71 point) increase in ICGI predicts an 0.093 increase in $\ln$ (Tobin's q), or about a $17 \%$ increase in share price for a firm with median Tobin's $q(1.54)$ and median debt/total assets $(0.66) .{ }^{12}$

11 Following Black and Khanna (2007), we construct 15 industry groups, of which 11 are represented in our sample. The industries (number of firms) are: agriculture and manufacturing (151); chemicals (42); services (25); computer (20); finance (15); construction (10); trade (9); metals (8); transportation (7); energy (2); and other (7).

12 Tobin's $q=$ (debt/assets) + (market value of equity/assets). A shock to share price affects only the second term: Let $\mathrm{T}$ be the fractional increase in Tobin's $q$ and $\mathrm{S}$ be the fractional share price increase. $\mathrm{S}=\{[\mathrm{New}$ (market equity/assets)]/[Old (market equity/assets)] -1$\}=\{[\mathrm{New} q-$ (debt/assets)]/[Old $q$ - (debt /assets) -1$\}=\{[(\mathrm{Old}$ $q)^{*}(1+\mathrm{T})$ - (debt/assets)]/[Old $q$ - (debt/assets)] - 1\}. This equation can be solved for S if we know debt/assets, old $q$, and the fractional change $T$. 


\section{Table 13. $O L S$ for Corporate Governance Index with Different Control Variables}

Ordinary least squares regressions of $\ln$ (Tobin's q), $\ln$ (market/book), and $\ln$ (market/sales) on ICGI and control variables. We drop 12 outlier observations, based on $\mid$ studentized residual $\mid$ from regressing dependent variable on ICGI $>1.96$. $*$, **, and $* * *$ indicate significance levels at $10 \%, 5 \%$, and $1 \%$ levels. t-values, based on White's heteroskedasticityconsistent standard errors, are in parentheses. Significant results (at $5 \%$ or better) are shown in boldface.

\begin{tabular}{|c|c|c|c|c|c|}
\hline \multirow[t]{2}{*}{ Dependent variable } & \multicolumn{3}{|c|}{ Ln(Tobin's q) } & \multirow{2}{*}{\begin{tabular}{|c|}
$\boldsymbol{L}$ (market/book) \\
$(4)$
\end{tabular}} & \multirow{2}{*}{$\frac{\boldsymbol{L} \boldsymbol{n} \text { (market/sales) }}{(5)}$} \\
\hline & (1) & (2) & (3) & & \\
\hline$I C G I$ & $\begin{array}{c}0.0565 * * * \\
(4.10)\end{array}$ & $\begin{array}{c}0.0563 * * * \\
(3.96)\end{array}$ & $\begin{array}{c}0.0342 * * * \\
(2.75)\end{array}$ & $\begin{array}{c}0.0322 * * \\
(1.97)\end{array}$ & $\begin{array}{l}0.0400 * * \\
(2.11)\end{array}$ \\
\hline $\operatorname{Ln}$ (assets) & & $\begin{array}{c}-0.00578 \\
(0.18)\end{array}$ & $\begin{array}{c}-0.0957 * * * \\
(2.75)\end{array}$ & $\begin{array}{c}-0.0874 * * \\
(2.05)\end{array}$ & $\begin{array}{l}-0.076 \\
(1.39)\end{array}$ \\
\hline $\operatorname{Ln}$ (years listed) & & $\begin{array}{c}0.0616 \\
(1.08)\end{array}$ & $\begin{array}{c}0.0662 \\
(1.23)\end{array}$ & $\begin{array}{c}0.1262 * \\
(1.89)\end{array}$ & $\begin{array}{l}0.042 \\
(0.55)\end{array}$ \\
\hline Debt/Equity & & $\begin{array}{c}-0.0354 \\
(1.30)\end{array}$ & $\begin{array}{c}-0.00928 \\
(0.41)\end{array}$ & $\begin{array}{c}0.084 * * * \\
(2.93)\end{array}$ & $\begin{array}{c}-0.0615 \\
(1.04)\end{array}$ \\
\hline Sales Growth & & $\begin{array}{c}0.0528 * * \\
(2.39)\end{array}$ & $\begin{array}{c}0.0327 * \\
(1.65)\end{array}$ & $\begin{array}{c}0.0468 * * \\
(2.11)\end{array}$ & $\begin{array}{c}0.0424 \\
(1.15)\end{array}$ \\
\hline R\&D/Sales & & & $\begin{array}{c}11.08 * * * \\
(4.18)\end{array}$ & $\begin{array}{c}9.660 * * * \\
(3.63)\end{array}$ & $\begin{array}{c}16.744^{*} \\
(1.77)\end{array}$ \\
\hline Advertising/Sales & & & $\begin{array}{c}5.134 * * \\
(2.43)\end{array}$ & $\begin{array}{c}5.402 * * * \\
(2.65)\end{array}$ & $\begin{array}{l}5.16 * * \\
(2.17)\end{array}$ \\
\hline Exports/Sales & & & $\begin{array}{l}-0.195 \\
(1.52)\end{array}$ & $\begin{array}{l}-0.248 \\
(1.48)\end{array}$ & $\begin{array}{l}0.297 \\
(0.17)\end{array}$ \\
\hline PPE/Sales & & & $\begin{array}{c}-0.136 * * \\
(2.16)\end{array}$ & $\begin{array}{c}-0.0941 \\
(0.93)\end{array}$ & $\begin{array}{c}-0.0007 \\
(0.01)\end{array}$ \\
\hline Capex/PPE & & & $\begin{array}{c}0.0002 \\
(0.61)\end{array}$ & $\begin{array}{c}-0.0001 \\
(0.53)\end{array}$ & $\begin{array}{l}0.0003 \\
(0.73)\end{array}$ \\
\hline EBDIT/Sales & & & $\begin{array}{c}1.395 * * * \\
(3.97)\end{array}$ & $\begin{array}{c}0.9846 * * \\
(2.54)\end{array}$ & $\begin{array}{c}2.352 * * * \\
(4.92)\end{array}$ \\
\hline Market Share & & & $\begin{array}{l}1.317 \\
(1.65)\end{array}$ & $\begin{array}{c}1.969 * * \\
(2.31)\end{array}$ & $\begin{array}{l}-0.309 \\
(0.27)\end{array}$ \\
\hline Share Turnover & & & $\begin{array}{c}2.740^{*} \\
(1.79)\end{array}$ & $\begin{array}{l}1.607 \\
(0.90)\end{array}$ & $\begin{array}{c}4.752 * * \\
(2.45)\end{array}$ \\
\hline Foreign Ownership & & & $\begin{array}{c}0.0125 * * * \\
(3.65)\end{array}$ & $\begin{array}{c}0.0133 * * * \\
(3.54)\end{array}$ & $\begin{array}{c}0.017 * * * \\
(4.00)\end{array}$ \\
\hline Promoter Ownership & & & $\begin{array}{c}0.0005 * * \\
(2.18)\end{array}$ & $\begin{array}{c}0.0059 * * \\
(2.28)\end{array}$ & $\begin{array}{c}0.006 * * \\
(2.07)\end{array}$ \\
\hline Business Group Dummy & & & $\begin{array}{l}-0.071 \\
(0.83)\end{array}$ & $\begin{array}{l}0.063 \\
(0.62)\end{array}$ & $\begin{array}{c}0.0001 \\
(0.00)\end{array}$ \\
\hline Cross Listing Dummy & & & $\begin{array}{c}0.314 * * \\
(2.39)\end{array}$ & $\begin{array}{l}0.216 \\
(1.14)\end{array}$ & $\begin{array}{c}0.455^{* * * *} \\
(2.78)\end{array}$ \\
\hline MSCI Dummy & & & $\begin{array}{l}0.254 \\
(1.40)\end{array}$ & $\begin{array}{l}0.296 \\
(1.35)\end{array}$ & $\begin{array}{l}0.273 \\
(1.29)\end{array}$ \\
\hline Intercept Term & Yes & Yes & Yes & Yes & Yes \\
\hline Industry Dummies & Yes & Yes & Yes & Yes & Yes \\
\hline Sample Size & 264 & 254 & 250 & 255 & 260 \\
\hline Adjusted $R^{2}$ & 0.097 & 0.095 & 0.291 & 0.278 & 0.540 \\
\hline
\end{tabular}

Several control variables are significant and generally remain so with the alternate dependent variables. Larger firms have lower valuations. Firms which are intangible asset intensive, proxied by advertising/sales and $\mathrm{R} \& \mathrm{D} /$ sales, have higher valuations. More profitable firms have higher valuations, as do firms with higher ownership by the controlling shareholder or group and higher foreign ownership. In unreported regressions, we add interactions between ICGI and the significant control variables; none of the interaction terms are significant. 
Balasubramanian et al::

\section{E. Subindex Results}

We next examine which subindices are associated with $\ln (q)$. Table 15, regression (1) reports results if we include all five subindices as separate independent variables, in a regression otherwise similar to our "full controls" specification (Table 13, regression (3)). In robustness checks, we obtain similar results for each subindex by itself. In regression (1), Shareholder Rights Index is positive and marginally significant. Shareholder rights also seems to drive the association between ICGI and firm value for more profitable firms (regression (4)). The coefficients on Board Structure and Disclosure Indices in the full sample regression (1) are positive but insignificant. The coefficients on Board Procedure and Related Party Transactions are close to zero.

\section{Table 15. OLS Results for Subindices}

Ordinary least squares regressions of $\ln$ (Tobin's q) on ICGI and each subindex. Control variables and sample are the same as in Table 13, regression (3), and regressions are similar, except that we replace ICGI with five subindices as separate variables. $t$-values, based on White's heteroskedasticity-consistent standard errors, are reported in parentheses. Adjusted $R^{2}$ varies from 0.153 to 0.371 . *, **, and $* * *$ indicate significance levels at $10 \%, 5 \%$, and $1 \%$ levels. Significant results (at $5 \%$ level or better) are shown in boldface.

\begin{tabular}{|c|c|c|c|c|c|c|c|}
\hline \multirow{2}{*}{\multicolumn{2}{|c|}{$\begin{array}{l}\text { Dependent variable } \\
\text { Sample }\end{array}$}} & \multicolumn{6}{|c|}{ Ln(Tobin's q) } \\
\hline & & $\begin{array}{l}\text { Sample } \\
\text { size }\end{array}$ & $\begin{array}{l}\text { Board } \\
\text { Structure } \\
\text { Subindex }\end{array}$ & $\begin{array}{l}\text { Disclosure } \\
\text { Subindex }\end{array}$ & $\begin{array}{l}\text { Related Party } \\
\text { Subindex }\end{array}$ & $\begin{array}{c}\text { Shareholder Rights } \\
\text { Subindex }\end{array}$ & $\begin{array}{l}\text { Board Procedure } \\
\text { Subindex }\end{array}$ \\
\hline \multirow{2}{*}{ (1) } & \multirow{2}{*}{ All firms } & \multirow{2}{*}{250} & 0.044 & 0.061 & 0.003 & $0.062 *$ & 0.005 \\
\hline & & & $(1.22)$ & $(1.46)$ & $(0.09)$ & (1.89) & $(0.15)$ \\
\hline \multirow{2}{*}{ (2) } & \multirow{2}{*}{ BSE 500 firms } & \multirow{2}{*}{92} & 0.046 & -0.005 & -0.051 & 0.062 & -0.058 \\
\hline & & & $(0.64)$ & $(0.06)$ & $(0.73)$ & $(0.93)$ & $(0.72)$ \\
\hline \multirow{2}{*}{ (3) } & \multirow{2}{*}{ non-BSE 500 firms } & \multirow{2}{*}{158} & $0.072^{*}$ & -0.010 & 0.059 & 0.042 & -0.019 \\
\hline & & & $(1.75)$ & $(0.22)$ & (1.41) & $(1.20)$ & $(0.42)$ \\
\hline \multirow{2}{*}{ (4) } & \multirow{2}{*}{$\begin{array}{l}\text { More profitable firms } \\
(\mathrm{ROA}>15 \%)\end{array}$} & \multirow{2}{*}{129} & -0.004 & 0.041 & 0.036 & $0.130 * *$ & 0.063 \\
\hline & & & $(0.07)$ & $(0.56)$ & $(0.56)$ & (2.37) & $(1.01)$ \\
\hline \multirow{2}{*}{$((5)$} & \multirow{2}{*}{ High Ln(Tobin's q) } & \multirow{2}{*}{128} & 0.025 & 0.061 & 0.064 & 0.042 & -0.013 \\
\hline & & & $(0.58)$ & $(1.56)$ & $(1.50)$ & $(1.11)$ & $(0.31)$ \\
\hline
\end{tabular}

The weak results for Board Structure Index should be compared to the significant negative coefficient on a similar index in Black, de Carvalho and Gorga (2010b)'s study of Brazil, the positive coefficient in Dahya, Dimitrov and McConnell's (2008) multi-country study, and the strong positive coefficient on a similar index in Black and Kim (2010). If we divide Board Structure Index into Board Independence and Board Committee subindices, Board Independence subindex is not significant; Board Committee subindex is positive and marginally significant (coefficient $=0.062, t=$ 1.75). We also varied the definition of Board Independence subindex, with similar results. One reason why board independence is not strongly associated with market value is that India's minimum requirements for board independence are strict enough so that overcompliance (which provides the only variation we can test) does not predict firm value.

\section{F. Subsample Results}

We also divide the sample into various subsamples, and rerun the "full controls" specification from Table 13, regression (3). As Table 14 reports, ICGI predicts higher Tobin's q for 
more profitable firms, but not for less profitable firms. ${ }^{13}$ However, if we use a different specification, in which we add an interaction between ROA and ICGI to Table 13, regression (3), the interaction term is small and insignificant. We found no strong differences in the coefficient on ICGI for large versus small, high versus low growth, manufacturing versus non-manufacturing, and business group versus non-group subsamples.

\section{Table 15. OLS Results for Subsamples}

Ordinary least squares regressions of $\ln$ (Tobin's q) on ICGI for subsamples. Control variables and sample are the same as in Table 14, regressions (3)-(4). Sample is divided at the sample median. $t$-values, based on White's heteroskedasticity-consistent standard errors, are in parentheses. *, **, and *** indicate significance at 10\%, 5\%, and 1\% levels. Significant results (at 5\% or better) are shown in boldface.

\begin{tabular}{|c|c|c|c|c|c|}
\hline Dependent variable & & $\operatorname{Ln}(\mathrm{T}$ & bin's q) & & Ln(Market/Book) \\
\hline & $\begin{array}{l}\text { Sample (for } \\
\ln (\mathrm{q}) \text { ) }\end{array}$ & ICGI & Other Controls & Adjusted $R^{2}$ & ICGI \\
\hline Entire Sample & 250 & $\begin{array}{c}0.034 * * * \\
(2.75)\end{array}$ & Yes & 0.291 & $\begin{array}{c}0.032 * * \\
(1.97)\end{array}$ \\
\hline $\begin{array}{l}\text { More profitable firms } \\
\text { (Return on assets }>14.85 \% \text { ) }\end{array}$ & 129 & $\begin{array}{c}0.057 * * * \\
(3.35) \\
\end{array}$ & Yes & 0.265 & $\begin{array}{c}0.062 * * \\
(2.80)\end{array}$ \\
\hline $\begin{array}{l}\text { Less profitable firms } \\
\text { (Return on assets }<14.85 \% \text { ) }\end{array}$ & 121 & $\begin{array}{l}0.012 \\
(0.66)\end{array}$ & Yes & 0.188 & $\begin{array}{l}0.013 \\
(0.56)\end{array}$ \\
\hline
\end{tabular}

\section{G. Endogeneity Concerns}

Tables 14 and 15 provide evidence that firm-level governance is associated with higher $\ln$ (Tobin's q). We cannot assess causation because we have only cross-sectional data, and no plausible instrument for governance. But we can say at least a little bit about the likelihood that our results may provide decent guides to causation.

For emerging markets, little is known about the extent to which reverse causation (with better performance leading to better governance) or "optimal differences," in which governance optimally differs across firms, make cross-sectional results unreliable in assessing causation (Arcot and Bruno, 2006). For Korea, Black and Kim (2009) find weak evidence of reverse causation in Korea. Black, Jang and Kim (2006) report that firm characteristics, other than firm size, only weakly predict Korean firms' governance choices. This suggests that endogeneity due to firms' optimally choosing governance to reflect firm characteristics may not be a large concern.

We cannot assess the likelihood of reverse causation with our dataset. However, if governance were sensitive to a firm's circumstances, we might expect financial and ownership characteristics to predict governance. In unreported regressions, we assess whether the control variables used in Tables 14 and 15 predict firms' governance choices. Ln(assets), sales growth, and profitability predict higher ICGI scores. However, regardless of which independent variables we use, adjusted $R^{2}$ values are negative (and become more so as we add more control variables). This is consistent with the Black, Jang and Kim (2006) results for Korea, and suggests that the optimal differences flavor of endogeneity may be a limited concern in India as well.

13 Compare Black, de Carvalho and Gorga (2010b), who report that a Brazil governance index predict higher Tobin's q for both more profitable and less profitable firms, with similar coefficients; and Hutchinson and Gul (2004), who report that governance is more important for Australian firms with high growth opportunities. 


\section{Implications for Corporate Governance in Emerging Markets}

In this part, we combine our findings with those from other "case studies" of emerging markets. We seek to draw an overall picture of what corporate governance elements emerge as important across countries. ${ }^{14}$ Our conclusions are tentative, for several reasons. First, endogeneity is an important concern. Yet most studies, including this one, rely on cross-sectional associations, so their results may not be robust. Time-series studies are preferable, but are still vulnerable to endogeneity concerns (e.g., Wintoki, Linck and Netter, 2008). Second, different studies use different governance indices. The "shareholder rights" measure in one study may map only loosely onto the similarly named measure in another study. Third, different countries have different regulatory minima, which affect the elements on which there is within-country variation, and the range of that variation.

Generalizing turns out to be difficult. Most studies find an association between a governance measure and Tobin's q, but Connolly, Limpaphayom and Nagarajan (2008, Thailand) do not, at least without extensive digging. Which governance elements predict higher firm value also varies across countries. This suggests that flexibility in governance rules, above a regulatory minimum, would be valuable.

Board structure and outside directors. There is evidence that the combination of a minimum number of outside directors and an audit committee staffed principally by outside directors can be valuable, at least for larger firms. Black and Kim (2008) and Choi, Park and Yoo (2007) so find in Korea, and Black and Khanna (2007) find evidence that India's Clause 49 reforms, which were largely concerned with board structure and audit committees, raised the value of large firms relative to smaller firms. In this study, we find that board structure is positive and marginally significant for non-BSE-500 firms, but not for larger firms. These weak results could partly reflect the fairly high regulatory floor set by Clause 49 .

Disclosure. There is also evidence that better disclosure predicts higher firm value. Black, Kim, Jang and Park (2009) so find for Korea, with firm fixed effects, as do Black, Love and Rachinsky (2006) for Russia, again with firm fixed effects, and Cheung, Connelly, Limpaphayom and Zhou (2007) for Hong Kong in cross-section. We find a positive and marginally significant coefficient on disclosure for non-BSE 500 firms.

Shareholder rights. There is mixed evidence on whether a package of shareholder rights can predict higher firm value. Cheung, Jiang, Limpaphayom and Lu (2009) so find for mainland China, with firm fixed effects, as do we for India in cross-section. However, Cheung, Connelly, Limpaphayom and Zhou (2007) find an insignificant negative coefficient on the same measure of shareholder rights in cross-section in Hong Kong, and Black, Kim, Jang and Park (2009) find an insignificant, negative coefficient on a shareholder rights measure in Korea with firm fixed effects.

Related party transactions. There is mixed evidence on whether direct controls on related party transactions predict higher firm value. Black, Love and Rachinsky (2006) so find for Russia with firm fixed effects, but we find no significant effect for India in cross-section. However, part of the

14 The other research we draw on includes Black, Kim, Jang and Park (2009, Korea); Choi, Park and Yoo (2007, Korea directors); Black \& Kim (2008, Korea directors); Black \& Khanna (2007, India); Dharmapala and Khanna (2009, India); Cheung, Connelly, Limpaphayom and Zhou (2007, Hong Kong); Black (2001, Russia); Black, Love and Rachinsky (2006, Russia); Desai, Dyck and Zingales (2007) (Russia, tax enforcement) Cheung, Jiang, Limpaphayom and Lu (2009, China); Connolly, Limpaphayom and Nagarajan (2008, Thailand); Litvak (2007, effect of Sarbanes-Oxley Act on cross-listed firms). 
value added by independent directors may involve better control of related party transactions, so that even if they occur, they are less adverse to minority shareholders. Black and Kim (2008) find evidence of this for Korea with firm fixed effects. This indirect effect of governance on related party transactions would be captured by a board structure measure, rather than the related party transactions measure.

Board and committee procedures. Board and committee procedures are easy to measure, but there is as yet no good evidence that they predict firm value. Black, Kim, Jang and Park (2009) find an insignificant coefficient on a board procedures measure in Korea with firm fixed effects, as do we for India in cross-section.

Ownership parity. Black, Kim, Jang and Park (2009) find evidence for Korea, with firm fixed effects, that a measure of "ownership parity" (whether the largest shareholder has equal voting and economic rights) predicts higher firm value. A number of cross-country studies also find that higher ownership parity predicts higher firm value (e.g., Claessens, Djankov, Fan and Lang, 2002).

Firm size, profitability, and growth opportunities. It is plausible that large firms need different governance structures than small firms. Our results support this proposition - the overall association between ICGI and Tobin's $q$ is driven by the non-BSE 500 firms in our sample. On the other hand, Black, Kim, Jang and Park (2009) report similar results for large and small firms. We also find that the association between ICGI and Tobin's $q$ is present for high-profit (but not low profit) firms, and for firms with high Tobin's $q$, which proxies in part for growth opportunities (but not low- $q$ firms).

Our results for subsamples based on firm size and Tobin's $q$ are consistent with the arguments that firms with greater need for external capital benefit more from governance reform (Rajan \& Zingales, 1998; Durnev and Kim, 2005). Other studies do not examine subsamples divided in these ways; doing so could be a fruitful avenue for future research. Our results suggest that one-size does not fit all in governance, which implies that there should be room for firms to tailor governance to their own characteristics.

Inter-firm differences. Minimum mandatory rules can be valuable in some instances (Black and Khanna, 2007 (India); Black and Kim, 2008 (Korea)). At the same time, the benefits of "better" governance depend in part on firm characteristics. Moreover, governance regulations can sometimes impose larger costs than benefits. The U.S. Sarbanes-Oxley Act offers an example, both for U.S. firms and cross-listed foreign firms (Litvak, 2007; Zhang, 2009).

One response to inter-firm variation would be a relatively low regulatory floor, which mandates only governance structures that are likely to benefit all or most firms. Another would involve a comply-or-explain corporate governance code, of the sort used in the UK (see Arcot and Bruno, 2006) and a number of other countries. India is considering a proposal to allow greater customization of corporate governance rules in the form of the Indian Companies Bill 2008. This flexibility could well prove to be beneficial.

Cross-country differences. Different countries may have different corporate governance needs. For example, the mean and median Tobin's $q$ 's for our sample are over 2 (see Table 4). This suggests a combination of strong growth prospects for most firms and investors not expecting a high level of tunneling. In contrast, mean and median Tobin's $q$ levels are much lower in the other countries for which we have similar case study evidence, and are below 1 in Korea (Black, Kim, Jang and Park, 2009) and in the early years of the Russia study by Black, Love, and Rachinsky (2006), and are often a small fraction of 1 (suggesting high tunneling risk) in Black's (2001) study of Russian 
firms in 1999. This suggests that the core corporate governance problems may be different, either in kind or in intensity, across countries, and may call for different remedies.

Public enforcement. Dharmapala and Khanna (2009) provide evidence supporting the value of sanctions against Indian firms which did not comply with India's governance rules, and against their directors. This effect was found even though the change in official sanctions, which occurred in 2004, was not then (or since) followed by imposition of actual sanctions. Compare Bhattacharya and Daouk (2002, 2006), who report that enforced insider trading laws affect firm valuation, but unenforced laws do not. Desai, Dyck and Zingales (2007) provide evidence from Russia that enforcement of corporate income tax laws can benefit minority shareholders by limiting cash-flow tunneling.

\section{Conclusion}

We provide a detailed descriptive account of the governance practices of Indian public firms. Most firms meet the board independence rules under Indian law, which require either $50 \%$ outside directors or 1/3 outside directors and a separate CEO and board chairman, but 13\% (38 firms) do not. The board chairman often represents the controlling business group or other controlling shareholder. Firms are more likely to comply with audit committee requirement, although 1\% do not. Related party transactions are common (67\% of firms have RPTs representing 1\% of more of revenues), but approval requirements for them are often weak. For transactions with a controlling shareholder, only $7 \%(1 \%)$ of firms require approval by non-conflicted directors (minority shareholders). However, $78 \%$ of firms nominally require RPTs to be on "arms-length" terms, and $94 \%$ disclose them to shareholders. Only about $2 / 3$ rds of firms provide annual reports on their websites. For those which do not, there is no good alternate source. Executive compensation is modest by US standards, but CEOs face only a small risk of dismissal. Only about $75 \%$ of firms allow voting by mail, even though this has been legally required since 1956. Government enforcement actions against firms are almost nonexistent.

We also contribute to the literature on corporate governance indices and the connection between governance and firm value. We build a broad Indian Corporate Governance Index (ICGI) and examine the association between ICGI and firm market value. We find a positive and statistically significant association between ICGI and firm market value in India. This is consistent with prior research in other countries and in cross-country studies. The association is more significant for more profitable firms and firms with higher growth opportunities. A subindex for shareholder rights is individually significant, but subindices for board structure, disclosure, board procedure, and related party transactions are not significant. The non-results for board structure contrast to other recent studies, and suggest that India's legal requirements are sufficiently strict so that overcompliance does not produce valuation gains.

\section{REFERENCES}

Aggarwal, Reena, Isil Erel, Rene M. Stulz, and Rohan Williamson (2006). "Do U.S. Firms Have the Best Corporate Governance? A Cross-Country Examination of the Relation between Corporate Governance and Shareholder Wealth." (working paper), at http://ssrn.com/abstract=954169.

Aggarwal, Reena, Leora Klapper, and Peter D. Wysocki (2005), "Portfolio Preferences of Foreign Institutional Investors," Journal of Banking and Finance, vol. 29, pp. 2919-2946.

Anant, T.C.A. and Omkar Goswami (1995) Getting Everything Wrong: India's Policies Regarding 'Sick' Firms, in Dilip MOOKHERJEe (ED.), IndiAn Industry: POLICIES AND PERFORMANCE. 
Arcot, Sridhar R. and Bruno, Valentina Giulia (2006), "One Size Does Not Fit All, After All: Evidence from Corporate Governance," Working Paper, at http://ssrn.com/abstract=887947

Atanasov, Vladimir Bernard Black, Conrad Ciccotello and Stanley Gyoshev (2007), "How Does Law Affect Finance: An Examination of Financial Tunneling in an Emerging Market", Working Paper, at http://ssrn.com/abstract $=902766$.

Balasubramanian, N., Bernard Black, and Vikramaditya S. Khanna (2009), "Firm Level Corporate Governance in India", working paper, at http://ssrn.com/abstract=992529.

Bae, Kee-Hong, Jun-Koo Kang and Jin-Mo Kim (2002), Tunneling or Value Added? Evidence from Mergers by Korean Business Groups," Journal of Finance vol. 57, 2695-2740.

Beiner, Stefan, Wolfgang Drobetz, Markus M. Schmid and Heinz Zimmerman (20067), "An Integrated Framework of Corporate Governance and Firm Valuation," European Financial Management, vol. 12, pp. 249-283.

Bertrand, Marianne, Paras Mehta and Sendhil Mullainathan (2002), "Ferreting Out Tunneling: An Application to Indian Business Groups," Quarterly Journal of Economics, Vol. 117, pp. 121-148.

Bhattacharyya, Asish K and Sadhalaxmi Vivek Rao (2005), "Economic Impact of 'Regulation on Corporate Governance': Evidence from India," at http://ssrn.com/abstract=640842.

Bhattacharya, Utpal, and Hazem Daouk (2002), The World Price of Insider Trading, Journal of Finance 57, 75108.

Bhattacharya, Utpal, and Hazem Daouk (2006), When No Law is Better than a Good Law, working paper, at http://ssrn.com/abstract $=558021$.

Black, Bernard, Hasung Jang and Woochan Kim (2006a), “Does Corporate Governance Affect Firms' Market Values? Evidence from Korea" Journal of Law, Economics and Organization, vol. 22, 366-413.

Black, Bernard, Hasung Jang and Woochan Kim (2006b), Predicting Firms' Corporate Governance Choices: Evidence from Korea, Journal of Corporate Finance, vol. 12, pp. 660-691.

Black, Bernard, Antonio Gledson de Carvalho and Erica Christina Rocha Gorga (2010a), "Does One Size Fit All in Corporate Governance? Evidence from Brazil," working paper, at http://ssrn.com/abstract=1434116.

Bernard Black, Antonio Gledson de Carvalho and Erica Christina Rocha Gorga (2010b), Corporate Governance in Brazil, Emerging Markets Review, vol. 11 (forthcoming) (http://ssrn.com/abstract=1152454)

Black, Bernard and Woochan Kim (2010), "The Effect of Board Structure on Firm Value: A Multiple Identification Strategies Approach Using Korean Data", working paper, at http://ssrn.com/abstract $=968287$.

Black, Bernard, Inessa Love \& Andrei Rachinsky (2006), "Corporate Governance Indices and Firms' Market Values: Time-Series Evidence from Russia", Emerging Markets Review vol. 7, 361-379 (2006).

Bernard Black, Woochan Kim, Hasung Jang \& Kyung-Suh Park (2009), How Corporate Governance Affects Firm Value: Evidence on Channels from Korea, at http://ssrn.com/abstract $=844744$

Bruno, Valentina G., and Stijn Claessens (2009), "Corporate Governance and Regulation: Can There Be Too much of a Good Thing?", Journal of Financial Intermediation, vol. xx, pp. yyy-zzz working paper, at http://ssrn.com/abstract $=956329$.

Cheung, Steven Yan-Leung, J. Thomas Connelly, Piman Limpaphayom, and Lynda Zhou (2007), Do investors really value corporate governance? Evidence from the Hong Kong market," Journal of International Financial Management and Accounting, 18, 86-122.

Cheung, Steven Yan-Leung, Ping Jiang, Piman Limpaphayom, and Tong Lu (2009), Corporate Governance in China: A Step Forward, xx European Financial Management yyy-zzz (forthcoming 2009).

Choi, Jongmoo Jay, Sae Won Park, and Sean Sehyun Yoo (2007), “The Value of Outside Directors: Evidence from Corporate Governance Reform from Korea," Journal of Financial and Quantitative Analysis, 42, 941962. 
Claessens, Stijn, Simeon Djankov, Joseph Fan, and Larry Lang (2002), "Disentangling the Incentive and Entrenchment Effects of Large Shareholdings," Journal of Finance, vol. 57, pp. 2741-2771.

CONFEDERATION OF INDiAn INDUSTRy, Desirable Corporate GOVERnANCE: A CODE (1998).

Connelly, J. Thomas, Piman Limpaphayom, and N. Nagarajan (2008), "Form Versus Substance: The Effect of Family Influence and Corporate Governance Practices on Firm Value in Thailand," working paper, University of Pittsburgh.

Dahya, Jay, Orlin Dimitrov, and John J. McConnell (2008), "Dominant Shareholders, Corporate Boards, and Corporate Value: A Cross-Country Analysis," Journal of Financial Economics, Vol. 87, pp. 73-100.

Deb, Saikat Sovan and Chakrapani Chaturvedula (2004), "Ownership Structure and Firm Value: Empirical Study on Corporate Governance System of Indian Firms", working paper, at http://ssrn.com/abstract=594221.

Desai, Mihir, Alexander Cyck, and Luigi Zingales (2007), “Theft and Taxes”, Journal of Financial Economics, vol. 84, 591-623.

Dharmapala, Dhammika, and Vikramaditya Khanna (2009), "Corporate Governance, Enforcement, and Firm Value: Evidence from India”, at http://ssrn.com/abstract=1105732.

Doidge, Craig, G. Andrew Karolyi and Rene M. Stulz (2007), Why Do Countries Matter So Much for Corporate Governance, Journal of Financial Economics, vol. 86, pp. 1-39.

Doidge, Craig, G. Andrew Karolyi and Rene M. Stulz (2009), "Has New York Become Less Competitive than London in Global Markets? Evaluating Foreign Listing Choices over Time, Journal of Financial Economics, vol. 91, pp. 253-277.

Drobetz, Wolfgang, Andreas Schillhofer and Heinz Zimmerman (2004), "Corporate Governance and Expected Stock Returns: Evidence from Germany," European Financial Management, vol. 10, pp. 267-293.

Durnev, Artyom, and E. Han Kim (2005), "To Steal or Not to Steal: Firm Attributes, Legal Environment, and Valuation," Journal of Finance, vol. 60, 1461-1493.

Ferreira, Miguel A., and Pedro Matos (2007), "The Colors of Investors' Money: The Role of Institutional Investors Around the World," Journal of Financial Economics, forthcoming, at http://ssrn.com/abstract $=885777$.

Hutchinson, Marion, and Ferdinand A. Gul (2004), "Investment Opportunity Set, Corporate Governance Practices and Firm Performance", Journal of Corporate Finance, vol. 10, pp. 595-614

Jackling, Beverly, and Shireenjit Johl, "Board Structure and Firm Performance: Evidence from India's Top Companies”, Corporate Governance: An International Review, vol. 17, pp. 492-509.

Khanna, Tarun, Joe Kogan, and Krishna G. Palepu (2006), "Globalization and Similarities in Corporate Governance: A Cross-country Analysis." Review of Economics and Statistics, vol. 88, pp. 69-90.

Khanna, Vikramaditya (2004) "Corporate Crime Legislation: A Political Economy Analysis" Washington University Law Quarterly, vol. 82, pp. 95-141.

Khanna, Vikramaditya (2009), "The Anatomy of Corporate Governance Reform in an Emerging Market: The Case of India", Working Paper.

Klapper, Leora F., and Inessa Love (2004), "Corporate Governance, Investor Protection and Performance in Emerging Markets," Journal of Corporate Finance, vol. 10, 703-728.

Kumar, Jayesh (2003), Does Ownership Structure Influence Firm Value? Evidence from India, Working Paper, at http://ssrn.com/abstract $=464521$.

Kumar, Jayesh (2003a), Agency Theory and Firm Value in India, Working Paper, at http://ssrn.com/abstract $=501802$.

Leal, Ricardo P.C., and Andre L. Carvalhal-da-Silva, Corporate Governance and Value in Brazil (and in Chile), in Florencio Lopez-de-Silanes and Alberto Chong, editors, Investor Protection and Corporate Governance - Firm Level Evidence Across Latin America xxx-yyy (2007), also available as Inter-American Development 
Bank Research Network Working Paper \#R-514 (2005) at http://www.iadb.org/res/pub_desc.cfm?pub_id=R-514.

Litvak, Kate (2007), The Impact of the Sarbanes-Oxley Act on Non-US Companies Cross-Listed in the US, Journal of Corporate Finance, Vol. 13, pp. 195-228.

Love, Inessa (2010), Corporate Governance and Performance Around the World: What We Know and What We Don't, World Bank Research Observer, vol. xx, pp. yyy-zzz.

Mohanty, Pitibas (2003), "Institutional Investors and Corporate Governance in India." National Stock Exchange of India Research Initiative Paper No. 15, at http://ssrn.com/abstract=353820.

Baker, Edward, Aron Gottesman, Matthew Morey \& Benjamin Godridge (2007), "Corporate Governance Ratings in Emerging Markets: Implications for Market Valuation, Internal Firm Performance, Dividend Payouts and Policy", working paper,

Patel, Sandeep A., Amra Balic and Liliane Bwakira (2002), Measuring Transparency and Disclosure at Firm Level in Emerging Markets" (working paper, Standard \& Poor's).

Rajan, Raghuram G., and Luigi Zingales (1998), Financial Dependence and Growth, American Economic Review, vol. 88, pp. 559-586.

REPORT OF THE COMMITTEE APPOINTED BY THE SEBI ON CORPORATE GOVERNANCE UNDER THE CHAIRMANSHIP OF SHRI KUMAR MANGALAM BirLa (1999).

Sarkar, Subrata and Jayati Sarkar (2000) "Large Shareholder Activism in Corporate Governance in Developing Countries: Evidence from India," International Review of Finance, vol. 1, pp. 161-194.

Singh, Deeksha A., and Ajai S. Gaur (2009), "Business Group Affiliation, Firm Governance, and Firm Performance: Evidence from China and India”, Corporate Governance: An International Review, vol. 17, pp. 411-425.

Wintoki, M. Babajide, James S. Linck \& Jeffry M. Netter (2008, "Endogeneity and the Dynamics of Corporate Governance", working paper, at http://ssrn.com/abstract=970986.

World Bank Report (2005), India: Role of Institutional Investors in the Corporate Governance of their Porffolio Companies.

Zattoni, Alessandro, Torben Pedersen, and Vikas Kumar, "The Peformance of Group-affiliated Firms During Institutional Transition: A Longitudinal Study of Indian Firms", Corporate Governance: An International Review, vol. 17, pp. 510-523.

Zhang, Ivy Xiying (2009), Economic Consequences of the Sarbanes-Oxley Act of 2002, Journal of Accounting Research (forthcoming). 